\title{
The Straight Talk Campaign in Uganda: Impact of mass media initiatives-Summary report
}

Susan E. Adamchak

Karusa Kiragu

Cathy Watson

Medard Muhwezi

Tobey C. Nelson

See next page for additional authors

Follow this and additional works at: https://knowledgecommons.popcouncil.org/departments_sbsr-hiv

Part of the Health Policy Commons, International Public Health Commons, Medicine and Health Commons, and the Public Health Education and Promotion Commons

How does access to this work benefit you? Let us know!

\section{Recommended Citation}

Adamchak, Susan E., Karusa Kiragu, Cathy Watson, Medard Muhwezi, Tobey C. Nelson, Ann Akia-Fiedler, Richard Kibombo, and Milka Juma. 2007. "The Straight Talk Campaign in Uganda: Impact of mass media initiatives-Summary report," Horizons Final Report. Washington, DC: Population Council. 


\section{Authors}

Susan E. Adamchak, Karusa Kiragu, Cathy Watson, Medard Muhwezi, Tobey C. Nelson, Ann Akia-Fiedler, Richard Kibombo, and Milka Juma 
The Straight Talk Campaign in Uganda: Impact of Mass Media Initiatives

\section{Summary Report}
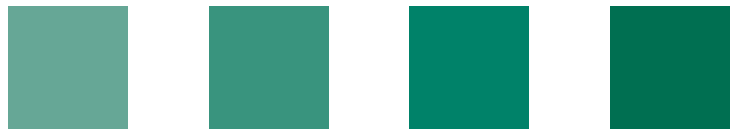

Horizons Program

Straight Talk Foundation 


\title{
The Straight Talk Campaign in Uganda: I mpact of Mass Media I nitiatives Summary Report
}

\author{
Susan E. Adamchak ${ }^{1}$, Karusa Kiragu ${ }^{2}$, Cathy Watson ${ }^{3}$, \\ Medard Muhwezi ${ }^{4}$, Tobey Nelson ${ }^{5}$, Ann Akia-Fiedler ${ }^{4}$, \\ Richard Kibombo ${ }^{6}$, and Milka J uma ${ }^{7}$
}
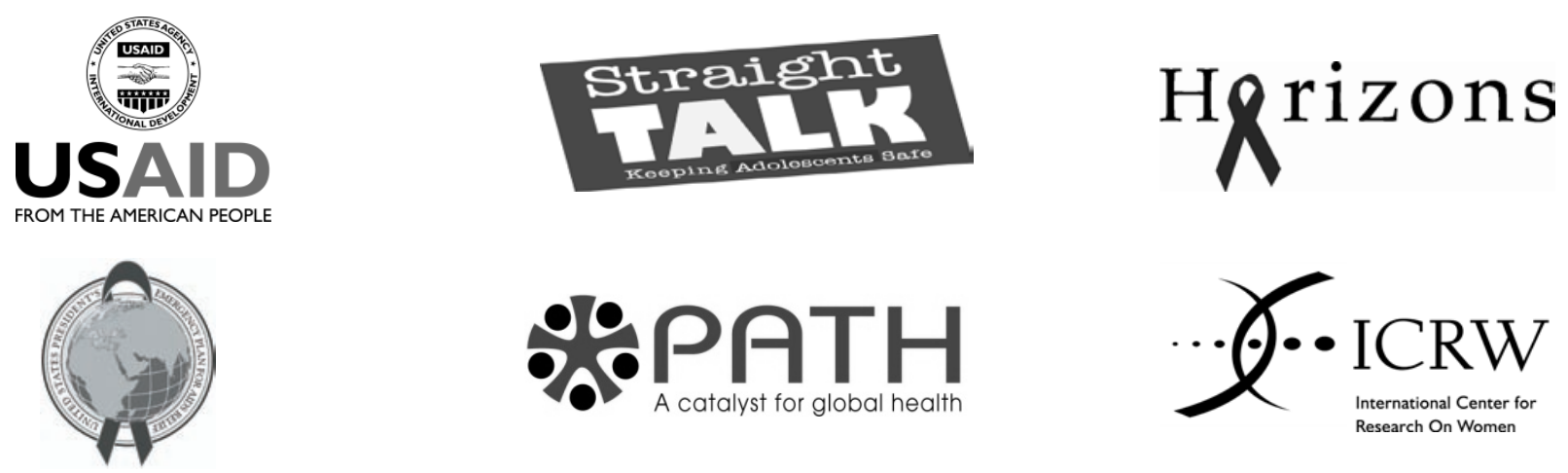

\footnotetext{
${ }^{1}$ Independent consultant

${ }^{2}$ Horizons/PATH, Nairobi

${ }^{3}$ Straight Talk Foundation, Kampala

${ }^{3}$ Formerly Straight Talk Foundation, Kampala

${ }^{5}$ Horizons/International Center for Research on Women, Washington DC

${ }^{6}$ Makerere University, Kampala

${ }^{7}$ Formerly Horizons-Population Council, Nairobi
} 


\section{Acknowledgments}

The principal investigators for this study were Karusa Kiragu (Horizons/PATH, Nairobi) and Tobey Nelson (Horizons/ICRW, Washington DC). Data collection was supervised by Richard Kibombo, an independent statistician consultant at Makerere University. Scott Geibel (Horizons/Population Council, Nairobi) was the data analyst for the study. The report was prepared by Karusa Kiragu and Tobey Nelson. Alison Lee (formerly of Horizons/Population Council, Washington DC) was in charge of copyediting and Sherry Hutchinson (Horizons/Population Council, Washington DC) oversaw the layout.

The research team would like to thank Straight Talk Foundation (STF) for their exceptional support including Cathy Watson (STF Director), Anne Akia Fiedler (formerly STF Programme director), Medard Muhwezi (formerly Head, Monitoring and Evaluation Section, STF), and the entire Monitoring and Evaluation Section. The team would also like to thank the entire School Environment Program (SEP) department at STF especially Beatrice Bainomugisha and Peter Mubala.

Special appreciation is extended to the teachers and learners who answered the questions in the survey.

The authors are grateful to the United States Agency for International Development (USAID) and the Department for International Development (DFID) for funding this evaluation.

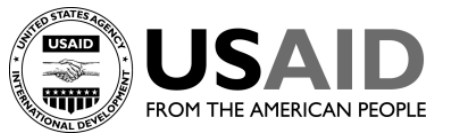

This study was supported by the Horizons Program, which is implemented by the Population Council in collaboration with the International Center for Research on Women, International HIV/AIDS Alliance, PATH, Tulane University, Family Health International, and Johns Hopkins University. Horizons is funded by the President's Emergency Plan for AIDS Relief through the U.S. Agency for International Development, under the terms of HRN-A-00-97-00012-00. The opinions expressed herein are those of the authors and do not necessarily reflect the views of the U.S. Agency for International Development.

Published in September 2007.

\section{(P Population Council}

The Population Council is an international, non-profit, nongovernmental institution that seeks to improve the well-being and reproductive health of current and future generations around the world and to help achieve a humane, equitable, and sustainable balance between people and resources. The Council conducts biomedical, social science, and public health research and helps build research capacities in developing countries. Established in 1952, the Council is governed by an international board of trustees. Its New York headquarters supports a global network of regional and country offices.

Copyright (C) 2007. The Population Council Inc.

Suggested citation: Adamchak, Susan E., Karusa Kiragu, Cathy Watson, Medard Muhwezi, Tobey Nelson, Ann Akia-Fiedler, Richard Kibombo, and Milka Juma. 2007. "The Straight Talk Campaign in Uganda: Impact of mass media initiatives, summary report,” Horizons Final Report. Washington, DC: Population Council.

This document may be reproduced in whole or in part without permission of the Population Council provided full source citation is given and the reproduction is not for commercial purposes. 


\section{Table of Contents}

\section{Abbreviations}

$\begin{array}{ll}\text { Executive Summary } & 1\end{array}$

$\begin{array}{ll}\text { Introduction } & 4\end{array}$

Background $\quad 4$

$\begin{array}{lr}\text { Survey Overview } & \mathbf{8}\end{array}$

Research questions $\quad 8$

Definition of exposure to ST materials $\quad 8$

Survey design and implementation $\quad 9$

Data processing and analysis $\quad 11$

Limitations of the survey $\quad 11$

Characteristics of the Sample $\quad 12$

Demographic characteristics 12

$\begin{array}{ll}\text { Schooling } & 13\end{array}$

$\begin{array}{ll}\text { Media utilization } & 15\end{array}$

Sources of I nformation on Reproductive Health 16

$\begin{array}{ll}\text { Exposure to Straight Talk products } & 16\end{array}$

$\begin{array}{ll}\text { What adolescents learned from Straight Talk products } & 17\end{array}$

Actions taken due to exposure to Straight Talk products 17

Reproductive Behavior and HIV Risk Exposure $\quad 19$

$\begin{array}{ll}\text { Sexual activity among adolescents } & 19\end{array}$

Transactional exchanges $\quad 21$

$\begin{array}{ll}\text { Future plans with partner } & 22\end{array}$

Condom use $\quad 23$

Reasons for never having sex $\quad 25$

$\begin{array}{ll}\text { Testing for HIV } & 26\end{array}$ 
I mpact of Straight Talk Activities: Findings of Multivariate Analysis

ASRH knowledge

Attitudes toward condoms

Attitudes toward gender equity

Self confidence

Summary of outcome results

Conclusions and Discussion

Background characteristics $\quad 35$

Use of ST materials $\quad 35$

ASRH knowledge $\quad 36$

ASRH attitudes $\quad 36$

Gender attitudes $\quad 37$

Self efficacy and self confidence $\quad 37$

Knowledge of STIs $\quad 37$

Use of health facility services $\quad 38$

$\begin{array}{ll}\text { Communication with parents } & 38\end{array}$

Support if child sexual abuse attempted 38

Sexual activity among adolescents 38

Condom use at last sex $\quad 39$

$\begin{array}{ll}\text { Reasons for never having sex } & 40\end{array}$

HIV testing $\quad 40$

$\begin{array}{ll}\text { Conclusion } & 40\end{array}$

$\begin{array}{ll}\text { References } & 41\end{array}$

Appendix 1: Sample Design 42

Appendix 2: Variable Definitions for Multivariate Analysis 44 


\section{Abbreviations}

$\begin{array}{ll}\text { ABC } & \text { Abstinence, Be faithful, Use condoms } \\ \text { AGI } & \text { Alan Guttmacher Institute } \\ \text { ASRH } & \text { Adolescent sexual and reproductive health } \\ \text { BCC } & \text { Behavior change communication } \\ \text { EA } & \text { Enumeration area } \\ \text { GYC } & \text { Gulu Youth Centre } \\ \text { HIV/AIDS } & \text { Human Immunodeficiency Syndrome/Acquired Immune Deficiency Disease } \\ \text { NGO } & \text { Non-governmental organization } \\ \text { OR } & \text { Odds ratio } \\ \text { OVC } & \text { Orphans and vulnerable children } \\ \text { PT } & \text { Parent Talk } \\ \text { PMCT } & \text { Prevention of mother-to-child transmission (of HIV) } \\ \text { ST } & \text { Straight Talk } \\ \text { STD } & \text { Sexually transmitted diseases } \\ \text { STI } & \text { Sexually transmitted infection } \\ \text { STF } & \text { Straight Talk Foundation } \\ \text { UBOS } & \text { Uganda Bureau of Statistics } \\ \text { UNICEF } & \text { United Nations Children's Fund } \\ \text { UDHS } & \text { Uganda Demographic and Health Survey } \\ \text { UNCST } & \text { Uganda National Council for Science and Technology } \\ \text { USAID } & \text { United States Agency for International Development } \\ \text { UHSBS } & \text { Uganda HIV/AIDS Sero-Behavioral Study } \\ \text { WHO } & \text { World Health Organization } \\ \text { VCT } & \text { Voluntary counseling and testing } \\ \text { YT } & \text { Young Talk }\end{array}$





\section{Executive Summary}

This report presents the findings of an evaluation of the Straight Talk (ST) mass media communication programs, which have been implemented in Uganda since 1993. The mass media programs largely comprise three main materials: multilingual Straight Talk Radio Shows, multilingual Straight Talk newspapers, and an English language Young Talk newspaper. Straight Talk also implements a wide array of school-based activities to engender a youth-friendly school environment. It has invested in many community activities such as community health fairs, and has worked to support youth-friendly health care services. The evaluation described here employed several strategies, including a household survey of adolescents, the main subject of this report. Other components included a household survey of parents, an assessment of the school environment and a cost study. ${ }^{1}$ The adolescent household survey was conducted with 2,040 males and females between the ages of 10 and 19 years. It was conducted in six districts in Uganda: Apac, Arua, Ntungamo, Soroti, Kisoro, and Kamuli. While ST has been active in all six districts, it has been particularly active in the first four. This study therefore allowed an assessment of the impact of ST in four high intensity and two low intensity districts. It also allowed an assessment of dose response, i.e., impact of incremental exposure to ST activities on specific outcomes. Data were gathered using faceto-face interviews after obtaining informed consent from the adolescent's parent or guardian, and from the adolescent himself or herself. The study was powered at 80 percent with a confidence of 95 percent. Analysis employed bivariate and multivariate methods.

\section{Sample}

Of the 2,040 adolescents in the survey, half were male, and the mean age was 14.5 years. About a quarter of the sample resided in urban areas, higher than the average Ugandan population of 15 percent. About 80 percent were either Catholic or Protestant. Slightly less than two-thirds of the youth lived with both parents, and those that lived with only one parent were much more likely to live with their mother than their father. There did not seem to be large differences between adolescent males and females with regards to living arrangements. About 84 percent of respondents were in school at the time of the survey, with slightly more males (86 percent) than females (81 percent) reporting school attendance. Most (80 percent) in-school adolescents in the study were in primary schools, indicating that many adolescents were old for their grade level.

\section{Use of ST Materials}

ST materials are designed to be audience-specific, with Young Talk newspaper aimed at primary schools, Straight Talk newspaper at secondary schools, and Straight Talk Radio Shows at older adolescents including those who are out of school and those who cannot read. The survey shows that ST materials have reached virtually all secondary and two-thirds of primary school students, as well as 56 percent of out-of-school youth. Adding local language ST products doubles exposure, and supports the value of vernacular communication materials in a multilingual environment like Uganda. The Straight Talk Radio Show remains the most popular product, followed by Young Talk newspaper and Straight Talk newspaper. Thus most young people surveyed were familiar with ST products and used them. Nearly 60

\footnotetext{
${ }^{1}$ These reports will be available from http://www.straight-talk.or.ug/downloads/downloads.html.
} 


\section{Hgrizons}

percent of exposed adolescents reported that the main message they had obtained from ST products was abstinence, indicating that ST programming is encouraging young people not to rush into sex. Indeed when asked what they were doing as a result of exposure to ST products, the most common response was "continuing to abstain." In this era of highly provocative and uncensored media, common on radio and in TV music videos, ST serves as a strong legitimizing voice for young people who do not wish to engage in sexual activity. It offers a healthy alternative to adolescents trying to make choices and to decipher the many complicated and contradictory messages on the airwaves.

\section{I mpact of ST Program on Knowledge, Attitudes, and Self Assuredness}

The results suggest that greater exposure to ST products is significantly associated with higher reproductive health knowledge, and each incremental exposure is associated with increased knowledge; this relationship holds for both males and females. Similar findings are documented regarding attitudes toward condoms, more gender-equitable perspectives, and greater self assuredness and self-confidence, especially among females.

\section{Sexual Activity and Condom Use}

About a quarter of the respondents reported that they had a boyfriend or girlfriend, and 12 percent of the study sample had ever had sex (15 percent of males and 9 percent of females). Multivariate analysis shows that among males, those exposed to all three ST items were only 39 percent as likely to be sexually active compared to their unexposed counterparts. Among females, the pattern was not clear or statistically significant. About 56 percent of sexually active boys and 70 percent of sexually active girls had had only one partner in their lives. Indeed 38 percent of boys who had ever had sex and 41 percent of their female counterparts had not had sex in the 12 months preceding the survey, and were thus practicing secondary virginity. Multivariate analysis shows that exposure to ST is associated with secondary virginity among males: males at the highest level of exposure were three times as likely to report practicing secondary virginity compared to their unexposed counterparts. The pattern among females is not clear, in part due to small sample sizes.

Just more than a quarter of the respondents planned to marry their current partner, with higher proportions of older youth, those in secondary school, and those out of school reporting this. ST exposure is associated with a greater likelihood of respondents considering their current relationship "serious" among males (OR 20.2) but not among females. Thus it is possible that these youth were adopting norms of fidelity promoted through Straight Talk as well as other sources in Uganda's comprehensive HIV prevention campaign.

Exposure to ST products is also associated with some increase in condom use, but the relationship is not statistically significant, largely due to the small sample size limiting statistical analysis. Half of the sexually experienced girls and 41 percent of boys reported having used condoms at their last intercourse. While two-thirds of the boys reported being responsible for using condoms, more than half the girls reported taking the initiative to use them. 


\section{HIV Testing}

Seven percent of the full sample, including 17 percent of the sexually experienced participants, had been tested for HIV. Urban and older youth were more likely to have been tested (they were also those most likely to be sexually active, so this is not surprising). Exposure to ST was clearly associated with having been tested (especially among those exposed to all three ST products), and with knowing whether a partner had been tested. Indeed multivariate analysis shows that respondents exposed to all three ST items examined were more than three times as likely to have been tested for HIV themselves.

\section{Conclusion}

This survey presents a rich source of information for programmers who are involved in adolescent sexual and reproductive health (ASRH). It indicates that many Ugandan adolescents have benefited from ST activities, and that greater exposure was associated with greater benefits. Among both males and females, exposure to ST activities is associated with greater ASRH knowledge, more balanced attitudes toward condoms, and more communication with parents about ASRH issues. The results also show that for girls, exposure to ST materials is further associated with greater self assuredness, greater sense of gender equity, and the likelihood of having a boyfriend but not having a sexual relationship. Among males, ST exposure is associated with lower likelihood of sexual activity, greater likelihood of resuming abstinence, and a greater likelihood of taking relationships with girls seriously. Thus ST may have protected many boys from HIV by helping them to stop sexual activity or to delay starting it all together. 


\section{Hgrizons}

\section{Introduction}

The Straight Talk (ST) program is perhaps one of the most successful ongoing media efforts to bring information about sexual and reproductive health to youth in Africa. The Straight Talk Foundation (STF) is widely recognized for grounding its programs in what young people want; it is careful not to call its efforts "campaigns," but rather "conversations" with adolescents. Consequently its activities are popular with young people. They are innovative, widespread in reach, and have endured over time. This report presents highlights of the findings of a program evaluation carried out in 2005-2006 to document the effect of ST activities on young people and parents in Uganda with particular attention given to the relationships between exposure to Straight Talk materials and behavior change efforts. The full report ${ }^{2}$, The Straight Talk Campaign in Uganda: Impact of Mass Media Initiatives, is available upon request.

\section{Background}

STF is a Ugandan health communications NGO that began work in 1997, growing out of a UNICEFfunded newspaper called Straight Talk, launched in October 1993. It appeared as a monthly insert in the main daily newspaper, The New Vision; extra copies were sent to secondary schools nationwide.

The first issues of Straight Talk attempted to communicate to several population groups, primarily older adolescents but also younger adolescents and parents. The aim was to influence adolescents to delay sex or practice safer sex if sexually active. The strategy was to talk directly to adolescents but also to help influential adults talk to them about safe behavior.

A critical influence on Straight Talk was a 1993 WHO survey of 35 sex education programs worldwide (Grunseit and Kippax 1993), which drew three key conclusions:

- Programs that succeeded in increasing the age of first sex were ones which urged youth to "postpone" sex. "Delay" was a more effective message than "no sex."

- Effective programs concentrated not just on facts about HIV transmission and reproduction, but also on skills such as decision-making.

- Sex education did not cause adolescents to start sex or be more sexually active.

The first issues of Straight Talk received input from a small group of doctors and counselors who gave credibility to the content. There was virtually no resistance to Straight Talk. This was the peak of the HIV epidemic in the country, and there were few messages for adolescents at the time. Uganda was open and seeking solutions.

Straight Talk was an immediate hit with older adolescents. Bright and deliberately non-frightening, it found a niche that no one else was serving, and where the need was acute. By the end of its first year in

\footnotetext{
${ }^{2}$ Adamchak, Susan E., Karusa Kiragu, Cathy Watson, Medard Muhwezi, Tobey Nelson, Ann Akia-Fiedler, Richard Kibombo, and Milka Juma. 2007. “The Straight Talk Campaign in Uganda: Impact of mass media initiatives.” Uganda: Straight Talk Foundation. This report will be available at http://www.straight-talk.or.ug/downloads/downloads.html.
} 
1994, it was receiving over 400 letters each month, and local versions of Straight Talk were starting up in Kenya and Tanzania.

However, the original inclusion of parents could not be maintained. Almost no adults wrote in, and combining content for parents and youth in one paper was editorially difficult. By May 1994 Straight Talk had narrowed its focus to older adolescents. It had a print run of 90,000, of which 35,000 were inserted into The New Vision, 32,000 into Ugandan-language newspapers, 15,000 posted to the 600 secondary schools then existing, and 13,000 distributed through NGOs.

For the next three years Straight Talk operated from a desk at The New Vision, but began doing more than just newspaper work. Following requests from head teachers, Straight Talk assembled a team and began visiting secondary schools in 1996. By 1997 Straight Talk had become an NGO, the Straight Talk Foundation. It began creating expanded systems to reach more adolescents.

With Straight Talk, a relatively "high-literacy" newspaper, STF was reaching only the 400,000 or so inschool, English-speaking, older adolescents aged 15 to 19 years. Two much larger groups were getting no information:

- Younger adolescents aged 10 to 14 years, about 700,000 of whom were in school.

- Out-of-school adolescents who could not access Straight Talk, either because they could not find a copy, read English, or read at all.

To reach the younger in-school adolescents, STF started Young Talk in March 1998. Studies showed that about 25 percent of upper primary pupils had had some sexual experience. Young Talk stressed delaying sex, child rights, life skills, and staying in school. Primary schools numbered over 9,000 in 1997, so from the start distribution was Young Talk’s key challenge.

To reach out-of-school adolescents, STF began working in radio. The English language Straight Talk Radio Show started in 1999. Ugandan language radio shows were added soon after: Luo (2000); Runyakitara (2001); Ateso (2002); Lugbara and Lumsamia (2003); Lumasaba, Luganda, and Lukhonzo (2004); Lusoga and Lupsabiny (2005); and Ngakarimojong (2006).

For the literate but non-English reading adolescents, STF began to produce newspapers in Ateso, Luo, Runyankole/Rukiga, Runyoro/Rutoro (the “Four R's), Luganda, and Lugbara. These were distributed at health fairs attended by local NGOs, local youth officials, and out-of-school youth.

With all of the above activity, STF was producing something - a radio show or newspaper-for much of the adolescent population, both in- and out-of-school and in urban and rural areas. By 2004 it was also running sensitizations for thousands of primary school teachers a year and overseeing over 700 Straight Talk clubs in schools.

In addition it added newspapers not strictly targeting adolescents or sexual health: Tree Talk, Teacher Talk, and Farm Talk in 2002; Kids Time in 2003 (addressing early childhood development), and Parent Talk in 2004.

As it grew, STF continually took stock of itself. About half of STF's staff comes from journalism and mass communications backgrounds, and the NGO is the first organization in Uganda to carry out public 


\section{Hgrizons}

sex education through the media. However, STF began to think of itself less as a media and increasingly as a behavior change organization.

As the HIV environment changed, it sought innovative ways to reach young people and help them to "rescript" their lives. Initially concerned about the lack of adolescent sexual and reproductive health (ASRH) information, STF soon realized that information alone was not enough. It tried to address the environment around adolescents and also tackle non-biomedical topics like love, jealousy, leisure, fun, and poverty.

It attempted to be always tasteful and socioculturally sensitive while staying forthright about sexuality. It thought of itself as engaging in a dialogue with adolescents, not executing a campaign. It took pride in allowing its readers and listeners to drive the content, and hosted dozens of high school and university volunteers. It saw itself as a voice for adolescents and by the mid 2000s was broadcasting over 7,000 interviews a year with adolescents. It also saw itself as an advocate for adolescents who are often stereotyped as reckless and stubborn.

Amid this growth, there were difficult questions to face about cost-effectiveness and focus. If STF was really committed to reaching the majority, why were newspapers in English its biggest core activity? STF was also worried about girls and out-of-school youth: why were 90 percent of letters to local language radio shows from boys? Why, if local language radio shows were for those not in school, were 75 percent of the letters from in-school adolescents?

In 2004-5 the "Abstinence, Be Faithful, Use Condoms” (ABC) controversy hit Uganda, causing two years of intense soul searching. For the first time, STF had to be self-conscious about what it was writing. There were hints from government that illustrations of reproductive organs and frank talk about condoms were no longer welcome in the school newspaper Straight Talk. How much should it change its tone, STF asked itself? How much self-censorship should it exercise? Had it been over-promoting condoms at the expense of abstinence? Or was it vice versa?

At root of all these questions was impact. After many years of implementation without a formal evaluation, STF wanted to assess its program. Were its activities changing the lives of adolescents? And if so, in what ways? Which of STF's products were being used and how? What messages were being recalled? Which adolescents were being reached? Which were not being reached? Did this vary between boys and girls? Did it vary by whether they were in urban or rural areas? Did it vary by whether they were in or out of school? STF had also started a program to reach parents in order to encourage supportive parent-child interaction. Therefore it desired to know more about parents: what were their views about STF materials? Did they know about them? Did they use them? Would they recommend them to their adolescent children? To answer these and other important questions, a comprehensive evaluation of STF activities was undertaken in 2005-2006. The evaluation comprised three components: a) a communitybased survey of adolescents and a sub-sample of their parents; b) a survey of teachers and youth; and c) a cost analysis.

This report presents highlights of the findings of the community-based survey ${ }^{3}$. The survey was conducted in six districts in Uganda. The second section of this report presents the methods used to implement the community-based survey. Subsequent sections are arranged thematically and cover sociodemographic characteristics of respondents, sources of ASRH information, reproductive behavior,

\footnotetext{
${ }^{3}$ Companion reports of the other evaluation components are available upon request from Straight Talk or at http://www.straighttalk.or.ug/downloads/downloads.html.
} 
and HIV risk exposure. Using key variables identified in the descriptive analysis, multivariate analyses were performed to better assess the impact of the STF program. The final part of this report offer conclusions and recommendations for the future. 


\section{Survey Overview}

\section{Research Questions}

The community-based household survey was designed to answer several questions related to ST campaigns, namely:

- What proportion of youth is reached by each Straight Talk mass media, community, and school activities?

- Do adolescents who are exposed to ST materials have higher knowledge and more positive attitudes toward safe behaviors than those who are not exposed to these media activities?

- Do adolescents who are exposed to ST materials practice more safe behaviors than those who are not exposed?

\section{Definition of Exposure to ST Materials}

The main ST materials being assessed in this study are a) ST radio shows, b) Straight Talk newspaper, and c) Young Talk newspaper. In order to assess the dose-response association between exposure to ST materials and the study outcomes, respondents have been classified into four groups: a) those not exposed to any item, b) those exposed to one item, c) those exposed to 2 items, and d) those exposed to all 3 items. This is the definition that will be used in the multivariate analysis (see below).

A second measure of exposure will be media intensity at the district level (see Box 1). STF has been implementing its activities at varying levels of intensity in different districts, largely due to funding shortfalls. As Box 1 shows, all districts receive the English Straight Talk and the English Young Talk ${ }^{4}$ newspaper. They also receive the weekly English ST youth radio show. In addition, four districts-Apac, Arua, Ntungamo, and Soroti-receive weekly half hour radio shows in their local language. They also receive occasional local language versions of the Straight Talk newspaper. This varying response has provided a natural experiment whereby some districts have more activities than others. For the purpose of this study, districts receiving just the English newspapers and English radio show are characterized as "low intensity." These are Kamuli and Kisoro districts. Those four districts receiving the English papers, English radio shows, a local language radio show, and the local language newspaper, are characterized as high intensity.

\section{Box 1 Definition of district media intensity by exposure to STF materials}

\begin{tabular}{|lcc|}
\hline & $\begin{array}{c}\text { High intensity districts } \\
\text { (Apac, Arua, Ntungamo, and Soroti) }\end{array}$ & $\begin{array}{c}\text { Low intensity districts } \\
\text { (Kamuli and Kisoro) }\end{array}$ \\
\hline Radio & English Straight Talk program & English Straight Talk program \\
Local language Straight Talk program & None \\
Newspapers & Young Talk (English) & Young Talk (English) \\
& Straight Talk (English) & Straight Talk (English) \\
& Local language Straight Talk & None \\
\hline
\end{tabular}

\footnotetext{
${ }^{4}$ Young Talk newspaper is only published in English language.
} 


\section{Survey Design and I mplementation}

\section{Sample design ${ }^{5}$}

The community-based survey targeted about 2,100 adolescents aged 10 to 19 years in six districts, namely Apac, Arua, Ntungamo, Kamuli, Kisoro, and Soroti. These districts were selected to provide a diverse geographic distribution of ST activities, including sites where ST has not been implemented, to serve as an artificial control. The sample size was powered at the 80 percent level and 95 percent confidence for selected indicators. This required 342 households per district, resulting in a total of 2,052 households in the survey. Each household was expected to yield one interview with an adolescent and half of them an interview with a parent. The sample was designed to accommodate refusals and not-at-homes by listing 20 percent more households per district for use when an interview was not possible.

In each participating district, two counties were selected for data collection; within each county, two subcounties were selected; and from them, two parishes were chosen. Thus a total of 12 counties, 24 subcounties, and 48 parishes were included in the survey. The Uganda Bureau of Statistics (UBOS) has divided each parish into an enumeration area (EA) which includes a list of all households. STF used the same list recently compiled for a household survey of adolescents conducted by ORC/Macro and Alan Guttmacher Institute (AGI) for this survey (Neema et al. 2006).

\section{Selection of respondents}

The household listing process had generated a list of households in which it was known that at least one of the occupants would meet the eligibility criteria for the study, which was specifically to be between the ages of 10 and 19 years and to normally reside in the identified dwelling. In each household, as many as two eligible adolescents would be eligible for interviewing, as long as they were not of the same sex or age grouping. A random numbers table was used to select one to be interviewed if there was more than one eligible adolescent. In each household, efforts were made to interview at least one adolescent between the age of 10 and 14 years, or 15 and 19 years, resulting in a 50/50 age-group split. Alternate households were to generate male and female adolescents, in order to achieve a 50/50 male/female split. Visiting adolescents were eligible if they spent the prior night at the household and if the consenting adult was their parent or guardian. Households headed by children under the age of 18 were excluded. The study also excluded married adolescents, since STF's main communication activities for adolescents are directed at unmarried adolescents. Interviews were completed with 2,133 adolescents; 93 questionnaires were subsequently deleted due to missing data on key variables, resulting in a sample of 2,040 adolescents. A total of 736 parents were interviewed but 58 of the questionnaires were also deleted due to missing data, leaving a sample of 678. By design, the sex distribution of both parents and adolescents was 50/50. Also by design, adolescents were evenly split between the 10-14 and 15-19 year age groups used by STF to guide programming. Data collection started on 29 August 2005 and ended on 7 September 2005.

Interviews were conducted by same-sex interviewers; i.e., male interviewers interviewed male respondents, and female interviewers interviewed female respondents. In about a third of the households, interviews of both a parent and an adolescent were conducted, matched by sex when possible.

\footnotetext{
${ }^{5} \mathrm{~A}$ full description of the sampling procedure is included in Appendix 1.
} 


\section{Hgrizons}

\section{Ethical clearance and gatekeeper approvals}

The questionnaires and consent forms were approved by the Uganda National Council for Science and Technology (UNCST). The study protocol was also reviewed and approved through Horizons' ethical review procedures. In each district, the study also sought the approval of district officials, community gatekeepers, and others as appropriate. Each respondent interviewed in the study provided written informed consent prior to commencement of the interview. Parental ${ }^{6}$ consent was obtained for all interviews with adolescents, in addition to the adolescent himself/herself providing informed consent. The questionnaires and consent forms were stored separately in order to ensure no identifying information could be linked.

\section{Study sites and populations}

The survey was implemented in six districts: Apac, Arua, Ntungamo, Soroti, Kamuli, and Kisoro. The first four districts were chosen because they had received the full battery of ST products, including English radio and print materials, local language radio and print materials, and school training. Kamuli and Kisoro were chosen as districts with low exposure to ST products (no local language materials or training), and serve as artificial controls.

\section{Data collection tools and administration}

The community-based household survey used face-to-face questionnaires: one for adolescents and one for parents. The adolescent questionnaire included skip patterns to move respondents aged 10-14 years past sections that were more appropriate for the older youth aged 15-19 years. Each questionnaire took about 30 to 45 minutes to complete. The questionnaires were translated into six languages - namely Ateso, Luo, Lugbara, Lusoga, 4Rs, and Rufumbira — and were administered by interviewers familiar with the local language. The questionnaires were pre-tested and revised twice before data collection. They were also reviewed by the data entry team, in order to identify problems that could hamper data entry.

\section{Interviewer training}

Interviewers were trained over a four-day period in August 2005. Sixty enumerators and 12 supervisors, including six STF monitoring and evaluation staff, were trained. Most of the enumerators were university students or graduates who had conducted interview research before, and many had worked with the UBOS. Training topics included the research questions, interviewing skills, household listing, respondent selection, call-backs, quality control, obtaining consent, and ethics in research. The interviewer training included a field practicum, after which the questionnaire was revised, finalized, and printed. In each district, the research team comprised about ten interviewers and a supervisor. Supervisors received training covering household listing, household selection, field work management, and other aspects to enhance quality control. Because one objective of the evaluation was capacity building, STF staff from the Monitoring and Evaluation department was involved in all aspects of data collection and fieldwork supervision.

\footnotetext{
6 "Parents" in this report includes guardians.
} 


\section{Data Processing and Analysis}

Once the data were collected, the supervisor reviewed the questionnaires and identified any problems needing correction. At the end of the day, the supervisor collated the questionnaires and entered them into a data collection registry. Each batch of questionnaires identified district, county, sub-county, and parish of origin. The consent forms were also collected, labeled, and stored in separate envelopes. The items were stored in a secure and locked box or room and prepared for shipping to Kampala for data entry.

Data entry at STF premises began as soon as data collection was over using EPI-DATA software version 3.02. The questionnaires were keyed twice to minimize data entry errors. Technical support for the data entry process was provided by a Makerere University statistician with technical support from the Horizons data analyst. Data cleaning yielded a small number of unusable and out of range questionnaires, reducing the sample to 2,040 adolescents, or 95 percent of initial target. Statistical analysis was conducted using SPSS and STATA software. It includes univariate, bivariate, and multivariate methods. It was initially planned to analyze the data using a one time, intervention-control design; however, preliminary analysis showed that even in the "control” sites, considerable spill-over exposure to ST products had occurred, reducing the utility of this strategy. The researchers decided to analyze the data by "dose response" approach, looking at whether there was an association between desired outcome and number of ST products a respondent had been exposed to.

\section{Limitations of the Survey}

Because the survey did not purport to provide district estimates, the interviews were distributed evenly across the districts, and no proportionate allocations were attempted. Another study limitation is social desirability bias. Even though respondents were informed that the interview was confidential and anonymous, and each respondent was interviewed in private, it is possible that some of them gave socially desirable answers. A third limitation pertains to the success of STF itself. While the study design planned to have two districts (Kisoro and Kamuli) act as controls, preliminary analysis showed that access to STF is widespread, and many respondents in both districts were already listening to the shows or using the materials. Therefore, the districts were re-classified as high intensity districts (Apac, Arua, Ntungamo, and Soroti) and low intensity districts (Kamuli and Kisoro). The cross-sectional study design does not allow for determination of cause and effect, only association. The reader is encouraged to keep these limitations in mind. 


\section{Characteristics of the Sample}

\section{Demographic Characteristics}

This report is based on the 2,040 adolescents retained after data cleaning. Half of the sample was male, and there was a near equal split between age groups (see Table 1). The mean age was 14.5 years, with males being slightly older than females (14.7 vs. 14.4 , $p=0.02$; data not shown). About a fourth of the sample resided in urban areas, and the remaining three-fourths lived in rural communities. About 80 percent were either Catholic or Protestant.

Table 1 Sociodemographic characteristics of respondents

\begin{tabular}{|c|c|c|c|c|c|c|}
\hline & \multicolumn{2}{|c|}{ Male } & \multicolumn{2}{|c|}{ Female } & \multicolumn{2}{|c|}{ Total } \\
\hline & Number & $\%$ & Number & $\%$ & Number & $\%$ \\
\hline \multicolumn{7}{|l|}{ Age } \\
\hline 10-14 & 500 & 49.0 & 510 & 50.0 & 1,010 & 49.5 \\
\hline 15-19 & 521 & 51.0 & 509 & 50.0 & 1,030 & 50.1 \\
\hline Total & 1,021 & 100.0 & 1,019 & 100.0 & 2,040 & 100.0 \\
\hline \multicolumn{7}{|l|}{ Residence } \\
\hline Urban & 257 & 25.2 & 249 & 24.4 & 506 & 24.8 \\
\hline Rural & 764 & 74.8 & 770 & 75.6 & 1,534 & 75.2 \\
\hline Total & 1,021 & 100.0 & 1,019 & 100.0 & 2,040 & 100.0 \\
\hline \multicolumn{7}{|l|}{ Religion } \\
\hline Catholic & 353 & 34.6 & 333 & 32.8 & 686 & 33.7 \\
\hline Protestant & 455 & 44.6 & 506 & 49.8 & 961 & 47.2 \\
\hline Muslim & 97 & 9.5 & 73 & 7.2 & 170 & 8.3 \\
\hline Saved/born again & 101 & 9.9 & 97 & 9.5 & 198 & 9.7 \\
\hline None, other & 14 & 1.4 & 7 & 0.7 & 21 & 1.0 \\
\hline Total & 1,020 & 100.0 & 1,016 & 100.0 & 2,036 & 100.0 \\
\hline \multicolumn{7}{|l|}{ Living arrangements } \\
\hline Both parents & 646 & 63.5 & 618 & 60.8 & 1,264 & 62.1 \\
\hline Father only & 54 & 5.3 & 48 & 4.7 & 102 & 5.0 \\
\hline Mother only & 176 & 17.6 & 171 & 16.8 & 347 & 17.1 \\
\hline Grandparents & 50 & 4.9 & 58 & 5.7 & 108 & 5.3 \\
\hline Aunt, uncle & 54 & 5.3 & 75 & 7.3 & 129 & 6.3 \\
\hline Sister, brother & 25 & 2.5 & 36 & 3.6 & 61 & 3.0 \\
\hline Other $^{\wedge}$ & 12 & 1.2 & 11 & 1.1 & 23 & 1.1 \\
\hline Total $^{\infty}$ & 1,017 & 100.0 & 1,017 & 100.0 & 2,034 & 100.0 \\
\hline
\end{tabular}

^Other includes boyfriend or girlfriend, cousin, other relative, friend, or alone.

$\infty$ Figures exclude missing values, which comprised 0.3 percent of respondents. 
Slightly less than two-thirds of the youth lived with both parents, and those that lived with only one parent were much more likely to live with their mother rather than their father. However, nearly 85 percent of adolescents lived with at least one of their parents. About one in six young persons lived with other relatives; this was slightly more the case for females than males. There did not seem to be large gender differences with regards to living arrangements.

\section{Schooling}

About 84 percent of respondents reported being currently in school, with slightly more males (86 percent) than females (81 percent) reporting school attendance (see Table 2 ). Roughly 2 percent of the adolescents had never attended school, with females slightly more likely than males to have never attended. Most (80 percent) in-school adolescents in the study were in primary school, indicating that many adolescents were old for their grade level. Over 90 percent attended mixed sex schools and about the same proportion were day scholars.

Those who dropped out of school $(n=279)$ were asked when they dropped out. Nearly 88 percent dropped out during primary school, including 83 percent of males and 92 percent of females. The main reason for dropping out was financial for both males (67 percent) and females (33 percent). However a substantial percentage of females also dropped out because of "work at home” (17 percent), illness (12 percent), lack of school supplies (12 percent), or lack of interest (11 percent). The percentages reported by males regarding these explanations were lower. On average, males dropped out of school at the age of 15.2 years, females at the age of 13.8 years $(p=0.000)$. 
Table 2 School attendance by various characteristics

\begin{tabular}{|c|c|c|c|c|c|c|}
\hline & \multicolumn{2}{|c|}{ Male } & \multicolumn{2}{|c|}{ Female } & \multicolumn{2}{|c|}{ Total } \\
\hline & Number & $\%$ & Number & $\%$ & Number & $\%$ \\
\hline \multicolumn{7}{|l|}{ Currently in school } \\
\hline Yes & 877 & 86.4 & 823 & 81.2 & 1,700 & 83.8 \\
\hline No & 128 & 12.6 & 151 & 14.9 & 279 & 13.8 \\
\hline Never attended & 10 & 0.1 & 39 & 3.8 & 49 & 2.4 \\
\hline Total & 1,015 & 100.0 & 1,013 & 100.0 & 2,028 & 100.0 \\
\hline \multicolumn{7}{|c|}{ Current level of education } \\
\hline Primary & 682 & 77.9 & 660 & 81.4 & 1,342 & 79.6 \\
\hline Post-primary & 193 & 22.1 & 151 & 18.6 & 344 & 20.4 \\
\hline Total & 875 & 100.0 & 811 & 100.0 & 1,686 & 100.0 \\
\hline \multicolumn{7}{|l|}{ Type of school } \\
\hline Mixed sex & 850 & 96.9 & 770 & 93.4 & 1,620 & 95.2 \\
\hline Girls only & 0 & - & 54 & 6.6 & 54 & 3.2 \\
\hline Boys only & 26 & 3.0 & 0 & - & 26 & 1.5 \\
\hline Total & 876 & 99.9 & 824 & 100.0 & 1,700 & 99.9 \\
\hline \multicolumn{7}{|l|}{ Type of student } \\
\hline Day student & 744 & 87.5 & 697 & 85.7 & 1,441 & 86.7 \\
\hline Boarder & 106 & 12.5 & 116 & 14.3 & 222 & 13.3 \\
\hline Total & 850 & 100.0 & 813 & 100.0 & 1,673 & 100.0 \\
\hline \multicolumn{7}{|c|}{$\begin{array}{l}\text { Highest education hope to } \\
\text { achieve }^{\wedge}\end{array}$} \\
\hline Primary & 58 & 6.6 & 84 & 10.2 & 142 & 8.4 \\
\hline Secondary & 279 & 31.9 & 316 & 38.5 & 595 & 35.1 \\
\hline Vocational school & 31 & 3.6 & 29 & 3.5 & 60 & 3.5 \\
\hline University/college & 390 & 44.6 & 301 & 36.7 & 691 & 40.8 \\
\hline Cannot tell & 116 & 13.3 & 91 & 11.1 & 207 & 12.2 \\
\hline Total & 874 & 100.0 & 821 & 100.0 & 1,695 & 100.0 \\
\hline \multicolumn{7}{|c|}{$\begin{array}{l}\text { Level at which stopped (among } \\
\text { those dropped out) }\end{array}$} \\
\hline Primary & 103 & 83.1 & 133 & 91.7 & 236 & 87.7 \\
\hline Secondary & 18 & 14.5 & 11 & 7.6 & 29 & 10.7 \\
\hline Vocational & 3 & 2.4 & 1 & 0.7 & 4 & 1.6 \\
\hline Total & 124 & 100.0 & 145 & 100.0 & 269 & 100.0 \\
\hline
\end{tabular}

^Among those currently in school 


\section{Media Utilization}

Respondents were asked how often they listened to the radio (see Table 3). The data show that males and females had sharply different radio listening patterns. Females were three times more likely to report that they did not listen to the radio at all than males (26 percent vs. 8 percent). Males were fifty percent more likely than females to report listening to broadcasts daily. Two-thirds of the sample resided in districts classified as having high media intensity in terms of ST publications and radio programs: Apac, Arua, Ntungamo, and Soroti.

Table 3 Media utilization

\begin{tabular}{lrr|rr|rr} 
& \multicolumn{2}{c|}{ Male } & \multicolumn{2}{c}{ Female } & \multicolumn{2}{c}{ Total } \\
& Number & $\%$ & Number & $\%$ & Number & $\%$ \\
\hline Radio listening per week & & & & & & \\
$\quad$ None & 76 & 7.5 & 253 & 25.6 & 329 & 16.5 \\
1-2 times & 186 & 18.4 & 205 & 20.7 & 391 & 19.6 \\
3-6 times & 293 & 29.0 & 229 & 23.2 & 522 & 26.2 \\
Daily & 449 & 44.5 & 302 & 30.5 & 751 & 37.6 \\
$\quad$ Total & 1,004 & 100.0 & 989 & 100.0 & 1,993 & 100.0 \\
District media intensity & & & & & & \\
$\quad$ High exposure & 675 & 66.1 & 680 & 66.7 & 1,355 & 66.4 \\
Low exposure & 346 & 33.9 & 339 & 33.3 & 685 & 33.6 \\
$\quad$ Total & 1,021 & 100.0 & 1,019 & 100.0 & 2,040 & 100.0 \\
Number of STF items & & & & & & \\
exposed to & & & & & & \\
$\quad$ None & 257 & 25.2 & 364 & 35.7 & 621 & 30.4 \\
$\quad$ One & 222 & 21.7 & 227 & 22.3 & 449 & 22.0 \\
$\quad$ Two & 230 & 22.5 & 180 & 17.7 & 410 & 20.1 \\
All three & 312 & 30.6 & 248 & 24.3 & 560 & 27.5 \\
$\quad$ Total & 1,012 & 100.0 & 1,019 & 100.0 & 2,040 & 100.0 \\
\hline
\end{tabular}




\section{Sources of I nformation on Reproductive Health}

\section{Exposure to Straight Talk Products}

All respondents were asked whether they "have ever listened to a radio program called Straight Talk" (see Table 4). About 55 percent of respondents said they had ever listened to this radio program, with males (60 percent) more likely to have done so than females (50 percent) $(\mathrm{p}=0.000)$. Respondents were also specifically asked whether they had ever read (not merely seen) the Straight Talk or Young Talk newspapers and could thereby be defined as having "used" these products. The data show that 49 and 39 percent respectively had ever read the Young Talk newspaper and Straight Talk newspapers. Thus of the three ST products, adolescents were most likely to have ever listened to the ST radio show, followed by Young Talk newspaper, then Straight Talk newspaper.

Table 4 Use of Straight Talk products

\begin{tabular}{lrcccc}
\hline Respondent characteristics & $\mathbf{n}$ & $\begin{array}{c}\text { Young Talk } \\
\text { newspaper } \\
\text { \% }\end{array}$ & $\begin{array}{c}\text { Straight Talk } \\
\text { newspaper } \\
\%\end{array}$ & $\begin{array}{c}\text { Straight } \\
\text { Talk radio } \\
\%\end{array}$ & $\begin{array}{c}\text { At least one } \\
\text { STF product } \\
\%\end{array}$ \\
\hline $\begin{array}{l}\text { Sex } \\
\quad \text { Male }\end{array}$ & 1,021 & 52.9 & 43.4 & 60.1 & 74.8 \\
$\quad$ Female & 1,019 & 44.3 & 34.7 & 50.3 & 64.3 \\
$\quad \begin{array}{l}\text { School status } \\
\quad \text { In school }\end{array}$ & 1,700 & 51.6 & 41.1 & 57.1 & 72.2 \\
$\quad$ Primary & 1,350 & 43.0 & 28.7 & 50.7 & 65.3 \\
$\quad$ Secondary & 348 & 85.1 & 90.2 & 81.6 & 99.4 \\
$\quad$ Out of school & 279 & 37.6 & 32.6 & 51.6 & 55.8 \\
Age group & & & & & \\
$\quad$ Males 10-14 & 500 & 41.8 & 29.8 & 51.0 & 64.4 \\
$\quad$ Females 10-14 & 510 & 34.9 & 23.5 & 44.5 & 55.9 \\
$\quad$ Males 15-19 & 521 & 63.5 & 56.4 & 68.9 & 84.8 \\
$\quad$ Females 15-19 & 509 & 53.6 & 46.0 & 56.2 & 72.7 \\
Residence & & & & & \\
$\quad$ Urban & 506 & 68.0 & 60.1 & 67.0 & 85.2 \\
$\quad$ Rural & 1,534 & 42.2 & 32.1 & 51.4 & 64.1 \\
District media intensity & & & & & \\
$\quad$ High intensity & 1,352 & 53.1 & 45.5 & 76.4 & 83.8 \\
$\quad$ Low intensity & 685 & 35.2 & 24.5 & 13.4 & 41.5 \\
Exposure to STF materials & & & & & \\
$\quad$ Not exposed & 621 & 0.0 & 0.0 & 0.0 & 30.4 \\
$\quad$ Exposed to 1 item & 449 & 30.1 & 4.9 & 63.5 & 22.0 \\
$\quad$ Exposed to 2 items & 410 & 72.9 & 54.1 & 68.8 & 30.1 \\
$\quad$ Exposed to 3 items & 560 & 99.5 & 98.8 & 100.0 & 27.5 \\
All respondents & $\mathbf{2 , 0 4 0}$ & $\mathbf{4 8 . 6}$ & 39.1 & 55.2 & $\mathbf{6 9 . 6}$ \\
\hline
\end{tabular}


Respondents were also classified by whether they had been exposed to zero, one, two, or three of the ST items (see Table 4). The data show that 621 respondents (30 percent) had not been exposed to any, 449 (22 percent) had been exposed to one item, 410 (20 percent) had been exposed to two items, and 560 (28 percent) had been exposed to all three items.

Respondents who said they listened to the Straight Talk radio show were asked how often they listened. The data show that 65 percent of those who listened said they did so three to four times a month (the show is broadcast weekly). The frequency at which respondents said they listened to the show was not appreciably different between high and low-intensity districts, suggesting that as long as the radio signal is received, respondents will listen.

Respondents who had ever read Straight Talk newspaper were asked how many issues they had read in a year, out of 12 possible issues (this inquiry was not made for Young Talk). Among the 80 percent who could recall a number (605), respondents had read a mean of 4.5 different issues. There were statistically significant differences by the various age-sex groupings, with older respondents more likely to have been exposed $(\mathrm{p}=0.004)$; in urban-rural residence, with urban respondents more likely to have been exposed $(\mathrm{p}=0.000)$; and by ST exposure $(\mathrm{p}=0.025)$.

ST readers were asked where they had obtained their last issue of Straight Talk and the majority (75 percent) mentioned school. Seven percent got it from home, 6 percent from friends, 3 percent from a health facility, and 3 percent from a community center. Virtually all respondents who were familiar with Young Talk and Straight Talk newspapers would recommend them to other young people their age (98 and 97 percent, respectively). A similar set of questions were asked about Young Talk and like Straight Talk, the majority (82 percent) found it at school, 6 percent from friends and 5 percent from home.

\section{What Adolescents Learned from Straight Talk Products}

All adolescents who had used any of the three ST products (i.e., ST radio show, Straight Talk and Young Talk newspapers) were asked what they had learned from them. The most common response was abstinence, reported by 60 percent of respondents. This was followed by delay of sex (11 percent) and HIV prevention (10 percent). All the other messages, including child defilement, how to prevent pregnancy, how to avoid STIs, body changes, staying in school, parent-child communication, etc. accounted for less than 2 percent of respondents each. There were only minor differences in the key messages by age or sex. Thus many adolescents see ST materials as strongly supportive of abstinence as a choice among adolescents.

\section{Actions Taken Due to Exposure to Straight Talk Products}

Respondents were asked what actions they took as a consequence of their exposure to ST products. Among the 57 percent of boys and 64 percent of girls reporting taking some action, the most common response was "continue to abstain," with nearly 70 percent of both males and females offering this reply. There was little variation by age or level of exposure. About 15 percent of the young people reported talking with a friend. Fifteen percent of boys and 12 percent of girls said they stopped having premarital sex. Fewer than 10 percent said they spoke with parents, started to use condoms, refused gifts for sex, 


\section{Hgrizons}

ceased spending time with peers whom were perceived to have a negative influence, or continued with their education. 


\section{Reproductive Behavior and HIV Risk Exposure}

\section{Sexual Activity Among Adolescents}

Survey respondents were asked whether they had ever had a boyfriend or girlfriend, and 24 percent of girls and 29 percent of boys answered affirmatively (see Table 5). As might be expected, there were large differences between younger and older respondents. Those reporting more exposure to ST materials, and those living in high media density districts, were somewhat more likely to report having a boyfriend or girlfriend, but this may also be confounded by residence in urban areas, with its greater opportunities for boys and girls to meet, mix, and spend time together and the fact that ST materials are targeted at older youth.

Table 5 Respondents who have every had a boyfriend or girlfriend or had sex

\begin{tabular}{|c|c|c|c|}
\hline Respondent characteristic & $\mathbf{n}$ & $\begin{array}{l}\text { Ever had } \\
\text { boyfriend or } \\
\text { girlfriend } \\
\%\end{array}$ & $\begin{array}{c}\text { Ever had sex } \\
\%\end{array}$ \\
\hline \multicolumn{4}{|l|}{ Sex } \\
\hline Male & 1,014 & 29.4 & 15.2 \\
\hline Female & 1,011 & 24.2 & 9.1 \\
\hline \multicolumn{4}{|l|}{ School status } \\
\hline In school & 1,688 & 22.9 & 8.9 \\
\hline Primary & 1,340 & 16.9 & 6.5 \\
\hline Secondary & 348 & 45.7 & 17.9 \\
\hline Out of school & 277 & 52.0 & 32.4 \\
\hline \multicolumn{4}{|l|}{ Age group } \\
\hline Males 10-14 & 496 & 12.3 & 5.6 \\
\hline Females 10-14 & 508 & 10.0 & 4.3 \\
\hline Males 15-19 & 518 & 45.8 & 24.4 \\
\hline Females 15-19 & 503 & 38.6 & 14.0 \\
\hline \multicolumn{4}{|l|}{ Residence } \\
\hline Urban & 503 & 32.8 & 14.8 \\
\hline Rural & 1,502 & 24.8 & 11.3 \\
\hline \multicolumn{4}{|l|}{ District media intensity } \\
\hline High intensity & 1,347 & 28.5 & 11.6 \\
\hline Low intensity & 678 & 23.5 & 13.3 \\
\hline \multicolumn{4}{|l|}{ Exposure to STF materials } \\
\hline Not exposed & 614 & 15.3 & 10.0 \\
\hline Exposed to 1 item & 446 & 21.7 & 10.5 \\
\hline Exposed to 2 items & 408 & 27.0 & 12.2 \\
\hline Exposed to 3 items & 558 & 43.4 & 15.9 \\
\hline All respondents & 2,025 & 26.8 & 12.2 \\
\hline
\end{tabular}




\section{Hgrizons}

Respondents were also asked whether they had ever had sex, and 15 percent of boys and 9 percent of girls reported that they had ${ }^{7}$. There were large differences comparing those in school and out of school (9 percent vs. 32 percent), reinforcing the hypothesis that school attendance has a protective effect against early sexual debut. Greater exposure to the program is associated with somewhat higher reports of sexual activity, seen here in exposure to ST products, but the percentage increase is small. It is likely that this represents self-selection among young people, who seek information because it is relevant to what they are doing in their lives. It may also reflect age: older adolescents are likely to be exposed to more ASRH information but are also more likely to be sexually active. The data also suggest that many adolescents do not immediately commence sexual relations, and this appears stronger as exposure to ST materials increases. For example, while 15 percent of those not exposed to any ST materials reported a girlfriend/boyfriend, 10 percent also reported ever having had sex. On the other hand, while nearly 43 percent of those exposed to three items had ever had a boyfriend/girlfriend only 16 percent had had sex. This suggests that those exposed to more materials may be more careful about the extent of their sexual involvement.

Sexually active respondents were asked to state the number of people they had ever had sex with (see Table 6). The data show that 61 percent of ever-sexually active respondents had had only one lifetime partner, including 55 percent of males and 70 percent of females. At the same time, it means that 40 percent of sexually active respondents, including 45 percent of males and 30 percent of females, had had multiple partners since sexual debut. Exposure to ST products generally shows mixed influence on the number of partners, again reflecting the possibility that sexually active youth may seek more information to learn more about the ramifications of their sexual behavior. More youth living in high media density districts reported having only one lifetime partner, indicating that they may have been responding to "safer sex" messages to be monogamous if they were sexually active. These factors were assessed using multivariate analysis.

Straight Talk materials encourage sexually active adolescents to resume abstinence, recognizing the sporadic nature of sexual behaviors among youth. The prevalence of secondary sexual abstinence was examined; nearly 40 percent of ever-sexually active adolescents, including 38 percent of males and 41 percent of females, had not had sex in the previous 12 months (see Table 6). Adolescents in high media districts were somewhat more likely to practice secondary abstinence, as were those exposed to more than one ST material, though the pattern was not as clear. Again, these factors were explored further using multivariate analysis.

\footnotetext{
${ }^{7}$ The remaining tables in this section include only the sexually active respondents.
} 
Table 6 Number of lifetime sexual partners and practice of secondary abstinence

\begin{tabular}{|c|c|c|c|c|c|}
\hline \multirow[t]{2}{*}{ Respondents characteristic } & \multirow[t]{2}{*}{$\mathbf{n}$} & \multicolumn{2}{|c|}{$\begin{array}{l}\text { Number of lifetime } \\
\text { sexual partners (\%) }\end{array}$} & \multirow[t]{2}{*}{$\mathbf{n}$} & \multirow{2}{*}{$\begin{array}{c}\% \text { abstinent past } \\
12 \text { months among } \\
\text { ever had sex }\end{array}$} \\
\hline & & One & Two or more & & \\
\hline \multicolumn{6}{|l|}{ Sex } \\
\hline Male & 134 & 55 & 45 & 145 & 38 \\
\hline Female & 80 & 70 & 30 & 82 & 41 \\
\hline \multicolumn{6}{|l|}{ Age group } \\
\hline Males 10-14 & 25 & 68 & 32 & 27 & 48 \\
\hline Females $10-14$ & 17 & 88 & 12 & 21 & 62 \\
\hline Males 15-19 & 109 & 52 & 48 & 118 & 36 \\
\hline Females 15-19 & 63 & 65 & 35 & 61 & 34 \\
\hline \multicolumn{6}{|l|}{ District media intensity } \\
\hline High intensity & 139 & 65 & 35 & 147 & 42 \\
\hline Low intensity & 75 & 53 & 47 & 80 & 34 \\
\hline \multicolumn{6}{|l|}{ Exposure to ST materials } \\
\hline Not exposed & 52 & 62 & 39 & 58 & 38 \\
\hline Exposed to 1 item & 42 & 57 & 43 & 43 & 28 \\
\hline Exposed to 2 items & 47 & 62 & 38 & 46 & 46 \\
\hline Exposed to 3 items & 73 & 62 & 38 & 80 & 43 \\
\hline All respondents & $214^{1}$ & 61 & 39 & $227^{2}$ & 39 \\
\hline
\end{tabular}

${ }^{1} 34$ sexually active respondents (14 percent) did not answer this question; 221 sexually active respondents (9 percent) did not answer this question

\section{Transactional Exchanges}

Adolescents were asked, "In the past 12 months, have you had sex with someone from whom you received gifts or money in exchange for sex?” and in a separate question, whether they had given someone gifts or money in exchange for sex. Nearly equal proportions of males (29 percent) and females (32 percent) reported receiving gifts, but a far higher share of boys report giving gifts (43 percent vs. 10 percent) (see Table 7). We also observe a large difference among boys by school status: a third of those in school reported giving someone gifts or money, compared with nearly double (62 percent) of those out of school. Similarly, 22 percent of in-school boys reported receiving some token in exchange for sex, while 42 percent of those out of school did so. Clearly transactional sexual exchange is an important strategy among those out of school. 
Table 7 Received or gave gifts or money for sex in prior 12 months

\begin{tabular}{|c|c|c|c|c|c|c|c|c|c|}
\hline \multirow{2}{*}{$\begin{array}{l}\text { Respondent } \\
\text { characteristic }\end{array}$} & \multicolumn{3}{|c|}{ Males } & \multicolumn{3}{|c|}{ Females } & \multicolumn{3}{|c|}{ All } \\
\hline & $\mathbf{n}$ & $\begin{array}{c}\text { Received } \\
\text { gifts or } \\
\text { money } \\
\%\end{array}$ & $\begin{array}{c}\text { Gave gifts } \\
\text { or } \\
\text { money } \\
\%\end{array}$ & $\mathbf{n}$ & $\begin{array}{c}\text { Received } \\
\text { gifts or } \\
\text { money } \\
\%\end{array}$ & $\begin{array}{c}\text { Gave gifts } \\
\text { or } \\
\text { money } \\
\%\end{array}$ & $\mathbf{n}$ & $\begin{array}{c}\text { Received } \\
\text { gifts or } \\
\text { money } \\
\%\end{array}$ & $\begin{array}{c}\text { Gave gifts } \\
\text { or } \\
\text { money } \\
\%\end{array}$ \\
\hline \multicolumn{10}{|l|}{ School status } \\
\hline In school & 59 & 22.0 & 32.2 & 33 & 30.3 & 6.1 & 92 & 25.0 & 22.8 \\
\hline Primary & 35 & 22.9 & 37.1 & 20 & * & * & 55 & 27.3 & 25.5 \\
\hline Secondary & 26 & 19.2 & 26.9 & 12 & * & * & 38 & 21.1 & 21.1 \\
\hline Out of school & 38 & 42.1 & 62.2 & 28 & 35.7 & 14.3 & 66 & 41.5 & 41.5 \\
\hline \multicolumn{10}{|l|}{ Age group } \\
\hline $10-14$ & 15 & * & * & 9 & * & * & 24 & * & * \\
\hline 15-19 & 85 & 31.8 & 44.0 & 53 & 34.0 & 9.3 & 38 & 32.6 & 30.4 \\
\hline \multicolumn{10}{|l|}{ Residence } \\
\hline Urban & 29 & 27.6 & 39.3 & 19 & * & * & 48 & 29.2 & 27.7 \\
\hline Rural & 71 & 29.6 & 45.1 & 43 & 32.6 & 9.1 & 114 & 30.7 & 31.3 \\
\hline \multicolumn{10}{|l|}{$\begin{array}{l}\text { District media } \\
\text { intensity }\end{array}$} \\
\hline High intensity & 59 & 18.6 & 25.9 & 38 & 28.9 & 7.7 & 97 & 22.7 & 18.6 \\
\hline Low intensity & 41 & 43.9 & 68.3 & 24 & * & * & 65 & 41.5 & 44.7 \\
\hline \multicolumn{10}{|l|}{$\begin{array}{l}\text { Exposure to STF } \\
\text { materials }\end{array}$} \\
\hline Not exposed & 28 & 35.7 & 67.9 & 14 & * & * & 42 & 38.1 & 50.0 \\
\hline Exposed to 1 & 17 & $*$ & $*$ & 17 & * & * & 34 & 29.4 & 31.4 \\
\hline Exposed to 2 & 19 & * & * & 10 & * & * & 29 & 24.1 & 17.2 \\
\hline Exposed to 3 & 36 & 25.0 & 31.4 & 21 & * & * & 57 & 28.1 & 21.4 \\
\hline All respondents & 100 & 29.0 & 43.4 & 62 & 32.3 & 9.5 & 162 & 31.0 & 30.6 \\
\hline
\end{tabular}

*Denominators too small for meaningful analysis

It is difficult to draw any clear conclusions regarding the sexually active girls, as the sample sizes are too small to produce stable percent distributions in many of the variables. We are able to observe that a slightly higher proportion of girls reported receiving gifts, compared to boys. However, girls were far less likely to report having given money or a gift in exchange for sex, although more out of school girls reported this compared with those still in school.

Looking at the males, and the sample as a whole, a higher percentage of those not living in low media intensity districts or exposed to fewer ST products were likely to report either giving or receiving something in a sexual exchange. This appears to be one of the largest differences observed, and it may indicate that a higher dose exposure to ST products may reduce acceptability of transactional sex.

\section{Future Plans with Partner}

The sexually active respondents were asked, "Thinking about your last sex partner, what are your plans with him/her?” Slightly more than a fourth of both boys and girls reported planning to marry their partner 
(see Table 8). Not surprisingly, older youth, and those in secondary school or out of school, were more likely to report this (31 to 43 percent; data not shown). Greater exposure to ST products, both in the number of products and in high media density districts, is associated with higher percentages reporting planning to marry; it is possible that these youth were in more stable relationships and were adopting norms of fidelity promoted through ST as well as other sources in Uganda's comprehensive HIV prevention campaign. Those with less exposure were twice as likely to say they were simply friends with their partner. This relationship also proved significant in the more rigorous multivariate analysis found later in this report.

Table 8 Plans with most recent sexual partner

\begin{tabular}{|c|c|c|c|c|c|c|c|}
\hline $\begin{array}{l}\text { Respondent } \\
\text { characteristic }\end{array}$ & $\mathbf{n}$ & $\begin{array}{c}\text { Plan to } \\
\text { marry } \\
\%\end{array}$ & $\begin{array}{l}\text { Dating } \\
\%\end{array}$ & $\begin{array}{c}\text { Just } \\
\text { friends } \\
\%\end{array}$ & $\begin{array}{c}\text { Just met } \\
\%\end{array}$ & $\begin{array}{c}\text { No plans } \\
\%\end{array}$ & $\begin{array}{c}\text { Don't know } \\
\%\end{array}$ \\
\hline \multicolumn{8}{|l|}{ Sex } \\
\hline Male & 153 & 28.6 & 3.3 & 14.4 & 2.0 & 43.8 & 9.8 \\
\hline Female & 93 & 28.0 & 12.9 & 14.0 & 2.0 & 37.6 & 5.4 \\
\hline \multicolumn{8}{|l|}{ Schooling status } \\
\hline In school & 151 & 16.6 & 6.6 & 16.6 & 2.6 & 49.0 & 8.6 \\
\hline Primary & 88 & 5.7 & 8.0 & 19.3 & 2.3 & 58.0 & 6.8 \\
\hline Secondary & 64 & 32.8 & 6.3 & 12.5 & 3.1 & 34.4 & 10.9 \\
\hline Out of school & 88 & 43.2 & 6.8 & 11.4 & 1.1 & 29.5 & 8.0 \\
\hline \multicolumn{8}{|l|}{ Age group } \\
\hline Males 10-14 & 28 & 7.1 & 0.0 & 28.6 & 3.6 & 42.9 & 17.9 \\
\hline Females 10-14 & 22 & - & - & - & - & - & - \\
\hline Males 15-19 & 125 & 31.2 & 4.0 & 11.2 & 1.6 & 44.0 & 8.0 \\
\hline Females 15-19 & 71 & 33.8 & 12.7 & 11.3 & 2.8 & 33.8 & 5.6 \\
\hline \multicolumn{8}{|l|}{ Residence } \\
\hline Urban & 75 & 30.7 & 8.0 & 13.3 & 1.3 & 38.7 & 8.0 \\
\hline Rural & 171 & 25.7 & 6.4 & 14.6 & 2.3 & 42.7 & 8.2 \\
\hline \multicolumn{8}{|c|}{ District media intensity } \\
\hline High intensity & 157 & 30.6 & 7.0 & 11.5 & 3.2 & 40.1 & 7.6 \\
\hline Low intensity & 89 & 21.3 & 6.7 & 19.1 & 0.0 & 43.8 & 9.0 \\
\hline \multicolumn{8}{|l|}{$\begin{array}{l}\text { Exposure to STF } \\
\text { materials }\end{array}$} \\
\hline Not exposed & 60 & 16.7 & 3.3 & 23.3 & 0.0 & 45.0 & 11.7 \\
\hline Exposed to 1 item & 46 & 21.7 & 6.5 & 19.6 & 2.2 & 45.7 & 4.3 \\
\hline Exposed to 2 items & 50 & 30.0 & 4.0 & 6.0 & 4.0 & 48.0 & 8.0 \\
\hline Exposed to 3 items & 90 & 35.6 & 11.1 & 10.0 & 2.2 & 33.3 & 7.8 \\
\hline All respondents & 246 & 27.2 & 6.9 & 14.2 & 2.0 & 41.5 & 8.1 \\
\hline
\end{tabular}

- Percentages not calculated because of small sample size

\section{Condom Use}

The survey included several questions on condom use for sexually active youth. When asked whether they had used condoms at their last sexual event, half of the girls and 41 percent of boys reported that 


\section{Hgrizons}

they had used condoms (see Table 9). There were very large differences among residents of urban and rural areas; this probably represents issues of access, privacy, and availability of cash to purchase condoms. In one of the strongest associations seen, dose exposure to ST products appeared well associated with condom use; 56 percent of those exposed to three ST products used condoms at last sex, compared with 24 percent who had no exposure to ST. This relationship was shown to continue in the multivariate analysis.

Those who were sexually active but did not use condoms were asked to give the main reason why they did not (see Figure 1). The main reason, cited by 27 percent, was that they did not know about condoms. Appreciable minorities also said that condoms were not available, that they trusted their partner, or that they did not know why no condom was used. Straight Talk, moving cautiously during the recent debate about the "Abstain, Be Faithful, Use Condoms" campaign in Uganda, has downplayed discussion of condoms in the past few years, and these figures could be a reflection of that approach.

Table 9 Condom use at last sex, and who suggested use

\begin{tabular}{|c|c|c|c|c|c|c|}
\hline \multirow[t]{2}{*}{ Respondent characteristic } & \multirow{2}{*}{$\begin{array}{l}\text { Number } \\
\text { sexually } \\
\text { active } \\
(n=248)\end{array}$} & \multirow{2}{*}{$\begin{array}{l}\% \text { used } \\
\text { condom } \\
\text { last sex }\end{array}$} & \multirow{2}{*}{$\begin{array}{l}\text { Number } \\
\text { used } \\
\text { condom } \\
(n=108)\end{array}$} & \multicolumn{3}{|c|}{$\begin{array}{c}\text { Who suggested } \\
\text { condom be used (\%) }\end{array}$} \\
\hline & & & & Respondent & Partner & Both \\
\hline $\begin{array}{l}\text { Sex } \\
\text { Male } \\
\text { Female }\end{array}$ & $\begin{array}{r}155 \\
93\end{array}$ & $\begin{array}{l}40.6 \\
49.5\end{array}$ & $\begin{array}{l}63 \\
46\end{array}$ & $\begin{array}{l}66.1 \\
54.3\end{array}$ & $\begin{array}{l}19.4 \\
23.9\end{array}$ & $\begin{array}{l}14.5 \\
21.7\end{array}$ \\
\hline $\begin{array}{l}\text { Age group } \\
\text { Males 10-14 } \\
\text { Females 10-14 } \\
\text { Males 15-19 } \\
\text { Females 15-19 }\end{array}$ & $\begin{array}{r}28 \\
22 \\
127 \\
71\end{array}$ & $\begin{array}{c}14.3 \\
- \\
46.5 \\
56.3\end{array}$ & $\begin{array}{r}4 \\
6 \\
59 \\
40\end{array}$ & $\begin{array}{c}- \\
- \\
65.5 \\
52.5\end{array}$ & $\begin{array}{c}- \\
- \\
19.0 \\
27.5\end{array}$ & $\begin{array}{c}- \\
- \\
15.5 \\
20.0\end{array}$ \\
\hline $\begin{array}{l}\text { School status } \\
\text { In school } \\
\text { Primary } \\
\text { Secondary } \\
\text { Out of school }\end{array}$ & $\begin{array}{l}63 \\
88 \\
64 \\
40\end{array}$ & $\begin{array}{l}41.7 \\
25.0 \\
68.8 \\
44.4\end{array}$ & $\begin{array}{l}63 \\
22 \\
44 \\
40\end{array}$ & $\begin{array}{l}60.7 \\
- \\
62.8 \\
56.1\end{array}$ & $\begin{array}{c}19.7 \\
- \\
16.3 \\
26.8\end{array}$ & $\begin{array}{c}19.7 \\
- \\
20.9 \\
17.1\end{array}$ \\
\hline $\begin{array}{l}\text { Residence } \\
\text { Urban } \\
\text { Rural }\end{array}$ & $\begin{array}{r}75 \\
173\end{array}$ & $\begin{array}{l}69.3 \\
32.9\end{array}$ & $\begin{array}{l}52 \\
57\end{array}$ & $\begin{array}{l}59.6 \\
62.5\end{array}$ & $\begin{array}{l}15.4 \\
26.8\end{array}$ & $\begin{array}{l}25.0 \\
10.7\end{array}$ \\
\hline $\begin{array}{l}\text { District media intensity } \\
\text { High intensity } \\
\text { Low intensity }\end{array}$ & $\begin{array}{r}156 \\
92\end{array}$ & $\begin{array}{l}44.9 \\
42.4\end{array}$ & $\begin{array}{l}70 \\
39\end{array}$ & $\begin{array}{l}63.2 \\
57.5\end{array}$ & $\begin{array}{l}20.6 \\
22.5\end{array}$ & $\begin{array}{l}16.2 \\
20.0\end{array}$ \\
\hline $\begin{array}{l}\text { Exposure to STF materials } \\
\text { Not exposed } \\
\text { Exposed to } 1 \text { item } \\
\text { Exposed to } 2 \text { items } \\
\text { Exposed to } 3 \text { items }\end{array}$ & $\begin{array}{l}62 \\
47 \\
50 \\
89\end{array}$ & $\begin{array}{l}24.2 \\
44.7 \\
46.0 \\
56.2\end{array}$ & $\begin{array}{l}15 \\
21 \\
23 \\
50\end{array}$ & $\begin{array}{l}- \\
- \\
- \\
61.2\end{array}$ & $\begin{array}{c}- \\
- \\
- \\
18.4\end{array}$ & $\begin{array}{c}- \\
- \\
- \\
20.4\end{array}$ \\
\hline All respondents & 248 & 44.0 & 109 & 61.1 & 21.3 & 17.6 \\
\hline
\end{tabular}

- Percentages not calculated due to small sample size 
Figure 1 Reasons for not using condoms at last sex^

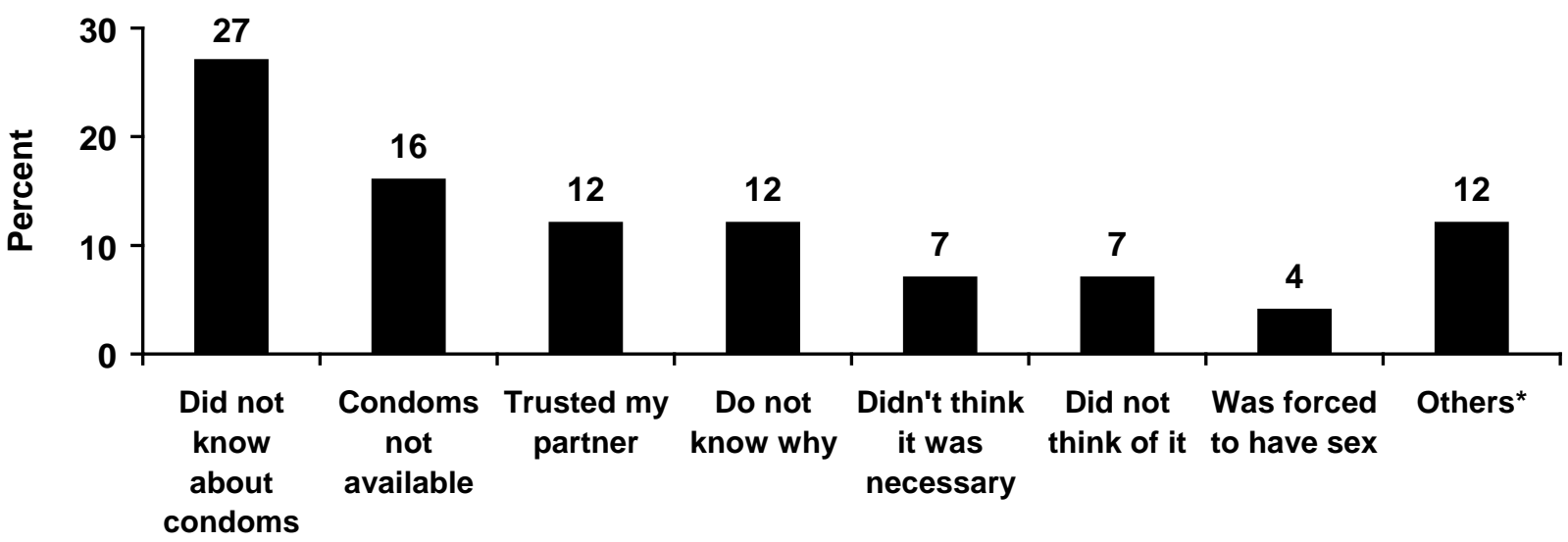

^Among the 138 nonusers who gave valid answers

*Includes not like condoms (4 percent), expensive ( 3 percent); partner objected ( 3 percent) and afraid to suggest (2 percent)

\section{Reasons for Never Having Sex}

Those who had never had sex were asked the main reason they had not done so (see Figure 2). The data show that fear of HIV was most salient reason offered, with a clear association with exposure to higher numbers of ST products as well as residence in high media density districts. This is followed by "not ready," "don't want to," and "not interested," reminding us that many adolescents are self-aware and able to monitor their sexual maturation responsibly. The risk of pregnancy was lower priority, particularly for males; fewer than 2 percent cited this as a reason to avoid sex, compared with 11 percent of females (data not shown).

Figure 2 Reasons for never having $\operatorname{sex}^{\wedge}$

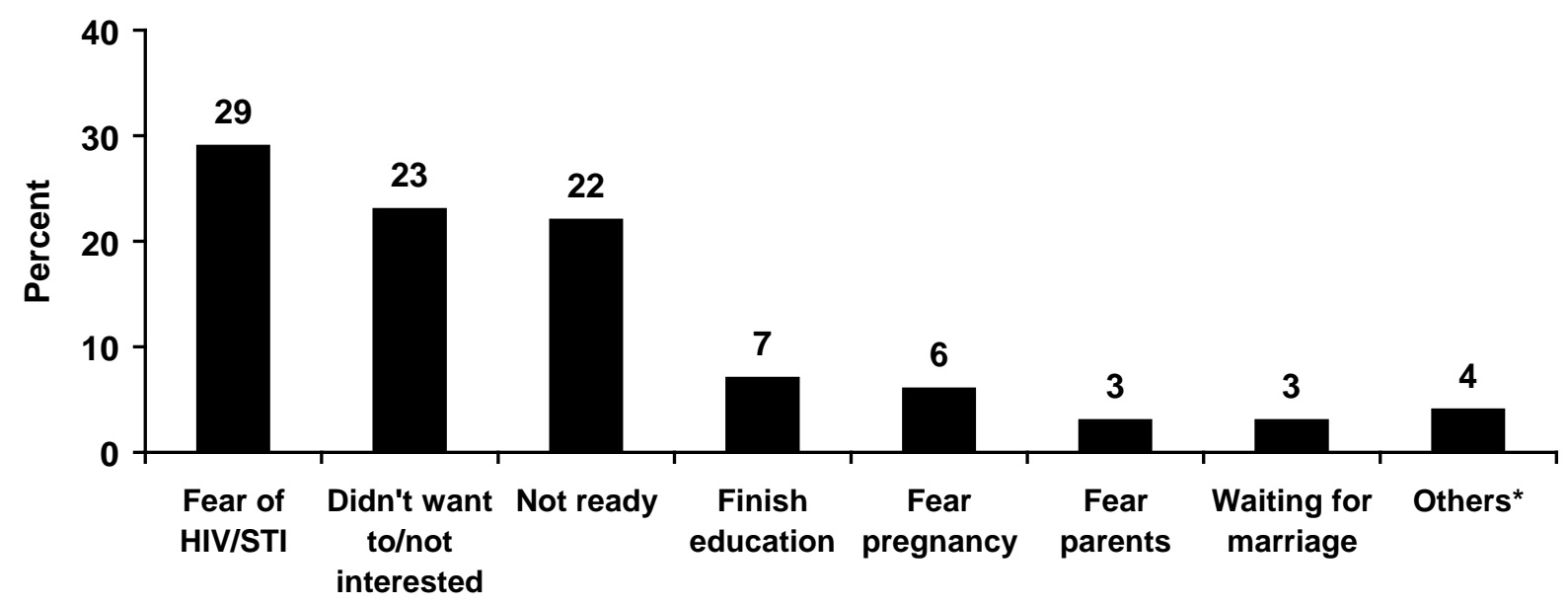

^Among the 1765 who have never had sex

* Includes advised against it (2 percent) and religion (2 percent) 


\section{Hgrizons}

\section{Testing for HIV}

Assured that the interviewer did not want to know the results, all respondents were asked whether they had been tested for HIV. Among the total sample, 7 percent reported having been tested (see Table 10). There were large differences by residence and by age, with urban and older youth more likely to have been tested. Among the sexually active young people, 17 percent had been tested, with more girls than boys reporting being tested (22 percent compared with 14 percent). A higher proportion of girls also reported that their partner had been tested. However, 82 percent of adolescents did not know whether their partner had been tested or, if s/he had been tested, what the results were. Exposure to ST materials was clearly associated with having been tested, and with knowing whether a partner had been tested, a relationship further illuminated through the multivariate analysis that follows.

Table 10 Respondent or partner ever tested for HIV

\begin{tabular}{|c|c|c|c|c|c|}
\hline & $\mathbf{n}$ & $\begin{array}{c}\% \text { ever tested } \\
\text { for HIV } \\
\text { (among all) }\end{array}$ & $\begin{array}{l}\text { Number } \\
\text { ever had } \\
\text { sex }\end{array}$ & $\begin{array}{l}\text { \% ever tested } \\
\text { for HIV among } \\
\text { ever had sex }\end{array}$ & $\begin{array}{l}\text { \% say most recent } \\
\text { partner tested for HIV } \\
\text { among ever had sex }\end{array}$ \\
\hline \multicolumn{6}{|l|}{ Sex } \\
\hline Male & 993 & 7.5 & 154 & 14.3 & 13.4 \\
\hline Female & 986 & 6.5 & 93 & 21.5 & 24.4 \\
\hline \multicolumn{6}{|l|}{ Age group } \\
\hline Males 10-14 & 482 & 2.5 & 27 & 0.0 & 8.0 \\
\hline Females 10-14 & 490 & 3.1 & 22 & 9.1 & 9.1 \\
\hline Males 15-19 & 511 & 12.1 & 127 & 17.3 & 14.5 \\
\hline Females 15-19 & 496 & 9.9 & 71 & 25.4 & 29.4 \\
\hline \multicolumn{6}{|l|}{ School status } \\
\hline In school & 1,652 & 5.9 & 153 & 12.4 & 14.5 \\
\hline Primary & 1,305 & 3.1 & 87 & 4.6 & 11.3 \\
\hline Secondary & 343 & 16.9 & 56 & 23.4 & 16.4 \\
\hline Out of school & 276 & 13.8 & 94 & 24.5 & 22.9 \\
\hline \multicolumn{6}{|l|}{ Residence } \\
\hline Urban & 491 & 12.6 & 75 & 28.0 & 26.0 \\
\hline Rural & 1,488 & 5.1 & 172 & 12.2 & 13.8 \\
\hline \multicolumn{6}{|l|}{$\begin{array}{l}\text { District media } \\
\text { intensity }\end{array}$} \\
\hline High intensity & 1,326 & 7.8 & 157 & 19.8 & 21.9 \\
\hline Low intensity & 653 & 5.2 & 90 & 12.2 & 10.5 \\
\hline \multicolumn{6}{|l|}{$\begin{array}{l}\text { Exposure to STF } \\
\text { materials }\end{array}$} \\
\hline Not exposed & 587 & 2.2 & 62 & 8.1 & 6.9 \\
\hline Exposed to 1 item & 435 & 4.6 & 47 & 14.9 & 14.0 \\
\hline Exposed to 2 items & 402 & 6.2 & 49 & 20.4 & 20.8 \\
\hline Exposed to 3 items & 555 & 14.4 & 89 & 22.5 & 25.3 \\
\hline All respondents^^ & $1,979^{\wedge}$ & 7.0 & $247^{*}$ & $17.0^{\circ}$ & 17.7 \\
\hline
\end{tabular}

^Data missing for 61 respondents (3 percent); ${ }^{\ddagger}$ Data missing for one respondent; ${ }^{\infty}$ Data missing for 15 respondents (6 percent) 


\section{Impact of Straight Talk Activities: Findings of Multivariate Analysis}

Because many outcomes examined in this research can be explained by other factors, it was necessary to conduct multivariate analysis, which allows for the control of these confounding influences. The variables used in the multivariate analysis are defined and explained in Appendix 2, and the results are presented in Tables 11 and 12, and summarized in Table 13. The data suggest that exposure to ST is associated with several desirable outcomes, when controlling for basic demographic characteristics as well as other mediating variables. The data also show that the strength of the associations may differ by sex.

\section{ASRH Knowledge}

The survey included a series of true/false questions to assess the level of ASRH knowledge among adolescents (see Appendix 2 for full definitions). The results show that despite years of intense media coverage and community dialogue about HIV in Uganda, there remains considerable room for improvement. One in five adolescents believe that AIDS can be cured, only 46 percent of adolescents believe that girls can get pregnant at first sex, only 45 percent are aware that a girl can get pregnant if she has sex standing up, and only 61 percent of adolescents believe that condoms are effective against STIs if used correctly. Knowledge about HIV is a bit higher: 71 percent are aware that a healthy-looking person can be HIV-positive, 78 percent know that AIDS cannot be cured, and 73 percent know that HIV can be passed from an infected mother to her child.

The knowledge questions were developed into a 6-point index by assigning one point to each correct response, and then dichotomizing the results (low knowledge 0-3 points; high knowledge 4-5 points). Multivariate analysis showed that greater exposure to ST is significantly associated with higher reproductive health knowledge, and each incremental exposure is associated with increased knowledge. Adolescents who were exposed to two items were 2.15 times more likely to score higher on the knowledge scale than those who were not exposed, and those exposed to all three items examined were 2.72 times more likely to have higher knowledge than their unexposed counterparts (last column, Table 11). The same pattern was observed by sex: males exposed to more ST items were more likely to score higher on the knowledge index, and those exposed to all three ST items were the most likely (three times more likely) to have higher knowledge than those who were not exposed to any items. Likewise, females who were exposed to all three ST items were 2.7 times more likely to have higher knowledge than their unexposed counterparts.

\section{Attitudes Toward Condoms}

Respondents were read a series of attitudinal questions they could agree or disagree with, or if they were not sure, they could also say so. They included statements such as "condoms are effective in protecting against STIs," "girls who carry condoms are loose," "buying condoms is the responsibility of males alone," and "using condoms is a sign of mistrust" (see Appendix 2 for full definitions). The results show that adolescents demonstrate uncertainty regarding many issues. For example, only a third disagreed that "using a condom is a sign that your partner does not trust you," suggesting that the remaining two-thirds 


\section{Hgrizons}

either agreed with the statement or were undecided. Likewise, only 38 percent disagreed with the statement "buying condoms is the responsibility of males only," indicating that many did not feel that girls should buy condoms. There seems a strong feeling that "girls who carry condoms are loose," with only 23 percent of adolescents disagreeing with this statement.

A 5-point scale was developed by awarding a point for each supportive response toward condoms. The final scale was dichotomized with those scoring 0 or 1 point considered to have negative attitudes and those with 2-4 points having positive attitudes. Multivariate analysis showed exposure to ST was associated with holding positive attitudes toward condoms. Adolescents who were exposed to all three items were the most likely to hold positive views, while those exposed to only two items were around two times as likely. This pattern holds among both males and females.

\section{Attitudes Toward Gender Equity}

The participants were also asked a series of questions to assess gender attitudes. These were agreedisagree questions, with a "don't know" option for those who could neither agree nor disagree. The questions are listed in Appendix 2. The results show that adolescents are quite intolerant of schoolgirl pregnancies: nearly three-quarters of both boys and girls agreed that girls who become pregnant should be expelled from school. They were just as intolerant of schoolboys who make schoolgirls pregnant: 79 percent of girls and 69 percent of boys thought that boys who made girls pregnant should be expelled.

When read the statement, "if money is scarce and the family cannot send all children to school, boys should be sent before girls," males were more likely to prefer preferential male treatment: 41 percent felt boys should be sent to school first, compared to 31 percent of girls. Forty-six percent of boys also said that men should have the final say about having sex, compared with 35 percent of girls. Equal proportions of boys and girls (57 percent) said that women should tolerate abuse in order to keep the family together, and 51 percent of girls and 48 percent of boys said there are times when a woman deserves to be beaten.

An 11-point gender-equity index was developed by awarding a point to each egalitarian response to the gender-related items listed in Appendix 2. Respondents were subsequently classified as having negative attitudes if they scored between 0 and 4, and having positive attitudes if they scored between 5 and 10 . Multivariate analysis showed that exposure to ST products is associated with more equitable gender attitudes among females. However, the pattern is not as clear among males. Each incremental exposure to ST materials among females is significantly associated with greater likelihood of scoring higher on the gender index. Among males, the pattern is in the desired direction but only exposure to one item is significantly associated with more equitable gender attitudes.

\section{Self Confidence}

In order to assess the adolescents' self-assuredness and social well-being, respondents were read a series of statements with which they could agree or disagree, or state if they were not sure. They explored areas such as self-satisfaction, feeling supported, feeling competent, and feeling socially well-adjusted (see Appendix 2 for the specific items). The results show that the vast majority of both boys and girls (90 percent) are happy with themselves. In addition, three-fourths of the boys and two-thirds of the girls felt they were as skilled and "can do things as well as most people my age." But the data also show that many 
lack self-confidence: for example, 36 percent of girls and 25 percent of boys did not believe they were as important in the family network as other family members. One in four girls, and one in eight boys wishes they had been born the opposite sex. Nearly 40 percent of the adolescents also felt that their friends were better than them, and a third doubted that they have a bright future.

As Table 11 shows, multivariate analysis reveals that adolescents who were exposed to two or three ST items were significantly more likely to report higher self-confidence than those who were not exposed to any item. For example, those who were exposed to two items were 1.42 times more likely to express higher self-confidence, while those exposed to three items were 1.53 more times more likely to express positive self-confidence. Analysis by sex shows that the pattern is particularly strong for girls but nondirectional for boys.

\section{Communication with parents/guardians about reproductive health}

STF has been engaged in activities to encourage parent-child communication, and youth in the survey were asked whether either of their parents/guardians had ever talked with them about "sexuality, growing up, relationships between boys and girls, etc.” Nearly half of the respondents reported having had some conversation with a parent or guardian on these topics, with girls (54 percent) more likely to report this than boys (42 percent).

ST exposure is significantly associated with ever having talked with parents about reproductive health matters, and the pattern is stronger for girls. Girls exposed to one item were 2.32 times more likely to have ever talked with a parent or guardian, those exposed to two items were slightly more likely (2.67 times) to have done so, and those exposed to three items were most likely (4.03 times) to have ever talked with parents. For males, the pattern is in the desired direction but statistical significance is not achieved until exposure to two or more items.

Among the young people who did not discuss sexual and reproductive health topics with their parents, the most commonly cited reason was embarrassment (32 percent), fearing their parents' reaction (23 percent), lack of interest (17 percent), don't know why (17 percent), do not see parent often enough (9 percent), parents not interested ( 9 percent), and being too young (9 percent).

\section{Ever having a boyfriend/girlfriend}

While bivariate analysis had suggested that exposure to ST materials was associated with having a boyfriend/girlfriend, controlling for covariates showed that there was no association between exposure to ST and having a relationship among males, and only slightly among females. Thus ST materials appear to be used by a cross-section of adolescents, including those in a relationship and those not involved in one. 


\section{Hgrizons}

Table 11 Adjusted odds ratio of specified outcome by exposure to Straight Talk materials

\begin{tabular}{|c|c|c|c|}
\hline Outcome variable & Males & Females & All \\
\hline \multicolumn{4}{|l|}{ High level of ASRH knowledge^ ${ }^{\wedge}$} \\
\hline Not exposed to any ST items & 1.00 & 1.00 & 1.00 \\
\hline Exposed to 1 item & $2.38^{*}$ & $1.44^{*}$ & $1.85^{\star}$ \\
\hline Exposed to 2 items & $2.78^{*}$ & $1.63^{*}$ & $2.15^{\star}$ \\
\hline Exposed to 3 items & $3.08^{*}$ & $2.46^{\star}$ & $2.72^{\star}$ \\
\hline $\mathrm{n}$ & 1,021 & 1,019 & 2,040 \\
\hline \multicolumn{4}{|c|}{ Positive attitudes toward condoms^^} \\
\hline Not exposed to any STF items & 1.00 & 1.00 & 1.00 \\
\hline Exposed to 1 item & $2.21^{*}$ & $2.09 *$ & $2.16^{*}$ \\
\hline Exposed to 2 items & $2.31^{*}$ & $2.22^{*}$ & $2.28^{*}$ \\
\hline Exposed to 3 items & $3.14^{*}$ & $3.12^{*}$ & $3.15^{\star}$ \\
\hline $\mathrm{n}$ & 1,021 & 1,019 & 2,040 \\
\hline \multicolumn{4}{|l|}{ Attitudes toward gender^^} \\
\hline Not exposed to any STF items & 1.00 & 1.00 & 1.00 \\
\hline Exposed to 1 item & $1.46^{*}$ & $1.51^{*}$ & 1.51 \\
\hline Exposed to 2 items & 1.23 & $1.63^{*}$ & 1.44 \\
\hline Exposed to 3 items & 1.37 & $1.73^{*}$ & 1.59 \\
\hline $\mathrm{n}$ & 1,021 & 1,019 & 2,040 \\
\hline \multicolumn{4}{|l|}{ Strong self confidence } \\
\hline Not exposed to any STF items & 1.00 & 1.00 & 1.00 \\
\hline Exposed to 1 item & 0.96 & 1.31 & 1.15 \\
\hline Exposed to 2 items & 0.93 & $2.11^{*}$ & $1.42^{*}$ \\
\hline Exposed to 3 items & 1.03 & $2.15^{\star}$ & $1.53^{*}$ \\
\hline $\mathrm{n}$ & 1,021 & 1,019 & 2,040 \\
\hline \multicolumn{4}{|c|}{ Has ever talked to parents about RH } \\
\hline Not exposed to any STF items & 1.00 & 1.00 & 1.00 \\
\hline Exposed to 1 item & 1.52 & $2.32^{\star}$ & $1.90^{*}$ \\
\hline Exposed to 2 items & $3.33^{*}$ & $2.67^{*}$ & $3.02^{*}$ \\
\hline Exposed to 3 items & $4.25^{\star}$ & $4.03^{\star}$ & $4.13^{\star}$ \\
\hline $\mathrm{n}$ & 1,021 & 1,019 & 2,040 \\
\hline \multicolumn{4}{|l|}{ Been tested for HIV } \\
\hline Not exposed to any STF items & 1.00 & 1.00 & 1.00 \\
\hline Exposed to 1 item & 2.37 & 0.94 & 1.44 \\
\hline Exposed to 2 items & 2.75 & 1.22 & 1.77 \\
\hline Exposed to 3 items & $3.98^{\star}$ & $3.48^{*}$ & $3.41^{*}$ \\
\hline $\mathrm{n}$ & 978 & 986 & 1,964 \\
\hline \multicolumn{4}{|l|}{ Has a boyfriend or girlfriend } \\
\hline Not exposed to any STF items & 1.00 & 1.00 & 1.00 \\
\hline Exposed to 1 item & $0.52^{*}$ & $1.88^{*}$ & 1.01 \\
\hline Exposed to 2 items & 0.85 & 1.74 & 1.22 \\
\hline Exposed to 3 items & 1.23 & $3.50 *$ & $2.01^{*}$ \\
\hline $\mathrm{n}$ & 1,014 & 1,011 & 2,025 \\
\hline
\end{tabular}

^Adjusted for age (continuous variable in years), access to radio (listens 0-3 days vs. 4-7 days), residence (urban vs. rural), living arrangements (both parents vs. either parent vs. neither parent), schooling status (in school vs. out of school), and sex (male or female; for last column).

* Odds ratio statistically significant at $p \leq 0.05$ 


\section{Ever having had sex}

Exposure to ST is associated with a lower likelihood of ever having had sex among males, but the pattern among females is not statistically significant (see Table 12). For example, males exposed to one ST item were only 0.39 times as likely to have ever had sex compared to other males who had not been exposed, those exposed to two items are only 0.50 times as likely, and those exposed to all three items are also only 0.39 times as likely. Among females, there is no association between ST exposure and sexual behavior; females exposed to ST were no more or less likely to engage in sexual activity than their unexposed counterparts. This could be a reflection that females are generally more sexually conservative and are less likely to have engaged in sex, and so may have nothing to report. However, because males are more likely to be sexually active, ST messages about abstinence may resonate with them and they may be able to do something about it. In addition, the small sample size among females may make it difficult to discern a clear pattern while the larger male sample size may make the pattern easier to discern.

\section{Table 12 Adjusted odds of safer sexual behavior by exposure to ST materials}

\begin{tabular}{|c|c|c|c|}
\hline Outcome variable & Males & Females & All \\
\hline \multicolumn{4}{|l|}{ Ever had sex } \\
\hline Not exposed to any STF items ${ }^{\wedge, *}$ & 1.00 & 1.00 & 1.00 \\
\hline Exposed to 1 item & $0.39 *$ & 1.10 & 0.62 \\
\hline Exposed to 2 items & $0.50^{*}$ & 0.81 & 0.64 \\
\hline Exposed to 3 items & $0.39 *$ & 1.45 & 0.66 \\
\hline $\mathrm{n}$ & 1,019 & 1,018 & 2,037 \\
\hline \multicolumn{4}{|l|}{ Used condoms at last $\operatorname{sex}^{\wedge^{, *, \infty}}$} \\
\hline Not exposed to any STF items & 1.00 & 1.00 & 1.00 \\
\hline Exposed to 1 item & 1.01 & 1.81 & 1.29 \\
\hline Exposed to 2 items & 1.22 & 1.95 & 1.08 \\
\hline Exposed to 3 items & 1.80 & 1.84 & 1.29 \\
\hline $\mathrm{n}$ & 152 & 92 & 244 \\
\hline \multicolumn{4}{|l|}{ Practicing secondary abstinence ${ }^{\wedge, *, \infty}$} \\
\hline Not exposed to any STF items & 1.00 & 1.00 & 1.00 \\
\hline Exposed to 1 item & 1.35 & 0.27 & 0.82 \\
\hline Exposed to 2 items & $3.57^{*}$ & 0.27 & 2.17 \\
\hline Exposed to 3 items & $2.94^{*}$ & 0.78 & 2.16 \\
\hline $\mathrm{n}$ & 145 & 82 & 227 \\
\hline \multicolumn{4}{|c|}{ Considers current sexual partner serious ${ }^{\wedge, *, \infty}$} \\
\hline Not exposed to any STF items & 1.00 & 1.00 & 1.00 \\
\hline Exposed to 1 item & 4.14 & 0.41 & 1.07 \\
\hline Exposed to 2 items & $6.54^{*}$ & $1.20^{\star}$ & 1.81 \\
\hline Exposed to 3 items & $20.18^{*}$ & $0.78^{*}$ & $3.04^{*}$ \\
\hline $\mathrm{n}$ & 155 & 93 & 248 \\
\hline
\end{tabular}

^Adjusted for age (continuous variable in years), access to radio (listens 0-3 days vs. 4-7 days), residence (urban vs. rural), living arrangements (both parents vs. either parent vs. neither parent), schooling status (in school and out of school), and sex (for last column).

${ }^{¥}$ Adjusted for the above items as well as knowledge $(0=$ low, $1=$ higher $)$, attitudes toward gender $(0=$ negative, $1=$ positive $)$, self confidence $(0=$ low confidence, $1=$ higher confidence $)$, and attitudes toward condoms $(0=$ negative attitudes, $1=$ positive attitudes), except when these are the outcome variables

${ }^{\infty}$ Among those ever had sex $(n=248)$

${ }^{*} \mathrm{p} \leq 0.05$ 


\section{Hgrizons}

\section{Use of condoms at last sex}

Sexually active adolescents appear incrementally more likely to use condoms at last sex if they are exposed to ST materials, though the pattern is not statistically significant.

\section{Practicing secondary abstinence}

The data suggest that once sexually experienced, males who are exposed to ST are more likely to resume being abstinent-for example, males exposed to two items were 3.57 times more likely to be secondary virgins compared to unexposed males, and those exposed to all three items were 2.94 times more likely to resume being abstinent. This pattern was not as evident among females, in part because of the small sample of sexually experienced females.

\section{Seriousness of a relationship}

Males exposed to ST were significantly more likely to consider their present sexual relationships serious, with marital aspirations, compared to those who were not exposed. Indeed adolescents exposed to all three items were 20 times more likely to consider a current relationship serious. This suggests less casual sexual involvement among males exposed to ST activities compared to their unexposed counterparts. On the other hand, the pattern for females is not as clear, in part because females in general consider relationships serious and thus exposure to ST may not alter that anticipation.

\section{HIV testing}

Multivariate analysis showed that adolescents who were exposed to ST were more likely to have ever been tested for HIV than those who had never been exposed, and this is particularly significant for those exposed to all three ST items examined. Males exposed to all three items were 3.98 times more likely to have been ever tested for HIV, and females were 3.48 more likely.

\section{Summary of Outcome Results}

The data suggest that ST is associated with certain positive outcomes in both males and females, in certain positive outcomes among males alone, and others in females alone (see Table 13). It appears that ST is significantly (i.e., statistically) associated with positive outcomes with respect to knowledge, attitudes toward condoms, parent-child communication, and awareness of one's HIV status. ST also appears to be associated with less likelihood of sexual activity among males but not females, with a greater likelihood of secondary virginity among sexually experienced males (but not females), and less likelihood of casual relationships among males (but not females). These associations are statistically significant. 
Table 13 Summary of outcomes by exposure to ST materials

\begin{tabular}{lcc}
\hline Outcome & Males & Females \\
\hline Greater knowledge & + & + \\
Positive attitudes toward condoms & + & + \\
Have talked to parents & + & + \\
Have taken HIV test & + but only at 3 STF items & + but only at 3 STF items \\
Have ever had sex & - & No difference \\
Now practicing secondary abstinence & + & No difference \\
Considers current sexual relationship serious & + & No difference \\
Greater self confidence & No difference & + \\
Positive gender equity attitudes & No difference & + \\
Have ever had a boyfriend/girlfriend & No difference & + \\
Used condoms at last sex & No difference & No difference \\
\hline
\end{tabular}

+ Indicates positive association between exposure and behavior

- Indicates negative association between exposure and behavior

On the other hand, ST is associated with greater self confidence among females (but not males), positive attitudes toward gender equity among females (but not males), and greater likelihood that a female has ever had a boyfriend (but no impact on males).

ST is marginally associated with a greater likelihood of using a condom at last sex, but this pattern does not achieve statistical significance (possibly because of the very small sample size).

It appears that ST is strongly associated with positive outcomes when those outcomes pertain to the respondent alone (e.g., knowledge, attitudes). But the impact is less when the response is mediated by the involvement of others, for example the involvement of parents in parent-child communication, the involvement of a health worker in HIV testing, etc. This is possibly because adapting the requisite behavior is more difficult when it involves the cooperation of others than when an individual can adopt it by themselves. 


\section{Hgrizons}

\section{Conclusions and Discussion}

Recent news that HIV prevalence is inching upwards in Uganda elevates the urgency of consistent communication efforts promoting HIV prevention. And because 71 percent of never-married women aged 15-19 years, as well as 60 percent of their male counterparts, have never had sex (MOH and ORC Macro, 2006) then messages toward adolescents have a chance to avert the epidemic in this key population. Things can change quickly though: only 2 percent of women aged 15-17 years in Uganda are HIVpositive, but this rises sharply to 8 percent by the time they reach 24 years. A similar pattern is evident among men, from 0.3 percent to 2.5 percent. This report presents an evaluation of Straight Talk Foundation's activities, designed to help Ugandan adolescents protect themselves against reproductive health hazards, particularly HIV. Based on a sample of 2,040 never-married male and female youth, this household survey demonstrates that STF has become an important influence on the reproductive knowledge, attitudes, and HIV prevention behaviors of Ugandan adolescents. It shows that STF activities are associated with different responses among males and females, differences that can be used to inform future HIV prevention messages.

This section summarizes the key findings of both analyses, and offers some interpretation of findings.

\section{Background Characteristics}

In this study of unmarried adolescents aged 10-19 years, half the respondents were male, and the mean age of the sample was around 15 years. About 84 percent were currently enrolled in school, including 81 percent of females and 86 percent of males. Not a single male reported never having attended school, whereas 4 percent of females said they had never attended. Of the 14 percent of students who started school and then dropped out, nearly 90 percent dropped at primary level. Two thirds lived with both parents, and those who lived with one parent were more likely to live with their mother (17 percent) than father (5 percent). Put together, about 84 percent of adolescents in the study lived with at least one biological parent.

Nearly all the in-school youth in the study attend a co-educational (i.e., mixed sex) school, and 87 percent were day scholars. About 80 percent were in primary school, suggesting a rather old-for-grade enrollment. Primary school in Uganda begins at around six years of age and ends at around 13 years of age. Since the mean age of respondents was 15 years, this would suggest that on average, the study sample should be in their second year in high school. That most had yet to graduate from primary school suggests delayed enrollment, grade repetition, and other factors that typically hold many Ugandan children back in class.

\section{Use of ST Materials}

ST materials are designed to be audience-specific, with Young Talk newspaper aimed at primary schools, Straight Talk newspaper aimed at secondary schools, and Straight Talk radio shows targeted to older adolescents including those who are out of school and those who cannot read. The survey shows that ST materials have reached virtually all secondary and two-thirds of primary school students, as well as 56 
percent of out-of-school youth. Adding local language ST products doubles exposure, and supports the value of vernacular communication materials in a multilingual environment like Uganda. The Straight Talk radio show remains the most popular product, followed by Young Talk newspaper, and then Straight Talk newspaper. Thus most young people surveyed were familiar with ST products and use them. Nearly 60 percent of exposed adolescents reported that the main message they had obtained from ST products was abstinence, indicating that ST programming is encouraging young people not to rush into sex. Indeed when asked what they were doing as a result of exposure to ST products, the most common response was "continuing to abstain." In this era of highly provocative and uncensored media, common on radio and on TV music videos, ST serves as a strong legitimizing voice for young people who do not wish to engage in sexual activity. It avails a healthy alternative to adolescents trying to make choices and to decipher the many complicated and contradictory messages on the airwaves.

\section{ASRH Knowledge}

The survey shows that greater exposure to ST activities is significantly associated with higher ASRH knowledge, and each incremental exposure is associated with increased knowledge; this relationship holds for both males and females. But despite years of intense media coverage and community dialogue about HIV in Uganda, there remains room for improvement in AIDS and reproductive health knowledge among young people. While it is unlikely that knowledge will ever become universal, continued efforts need to be directed, for example, to reducing the number of youth who believe AIDS can be cured. Knowledge that a person who looks healthy may be infected, and that a mother can pass the AIDS virus to her unborn child, increases substantially with exposure to any ST product. Urban residents are more knowledgeable than rural counterparts. Nevertheless, a large proportion of adolescents remain uninformed about HIV.

More so than informing youth about the risks of HIV, which are discussed in multiple media and venues across the country by any number of respected sources, there is a need to alert young people to basic sexual risks. More than half the group surveyed believes a girl cannot become pregnant the first time she has sex, and fewer than half understand that pregnancy can occur if a girl is standing during sex. Four in ten youth do not believe condoms are effective against STIs.

\section{ASRH Attitudes}

Exposure to ST media generally is associated with a more balanced perspective on ASRH attitudes, with not believing for example that condom use implies partner mistrust, that buying condoms is a male responsibility, and that girls who carry condoms are loose. Adolescents, both male and female, exposed to all three ST items are the most likely to hold positive values toward condoms. However, even those exposed to the most ST materials maintain some concerns about condom use. This suggests adolescents need help disentangling their views about condoms. In Uganda, the debate about condoms versus abstinence has become extremely intense, with many conflicting messages and opinions. The data suggests that ST is serving an important role, providing a balanced perspective that adolescents are responding to. 


\section{Hgrizons}

\section{Gender Attitudes}

The research shows that sizeable minorities of both boys and girls believe that boys should benefit when family resources are scarce. Nearly half of the boys and a third of the girls believe men are responsible for the final say about having sex. Half the respondents believe that women occasionally deserve to be beaten, and nearly 60 percent said that women should tolerate abuse in order to keep the family together. Thus many Ugandan adolescents have attitudes tolerant of gender-based violence and coercive sexual practices, both of which are likely to fuel HIV. The companion parents report from this study (Kiragu et al. 2007) shows that many Ugandan fathers and mothers themselves possess these unhelpful beliefs as well. Thus many adolescents may simply be reporting on what they have observed among their parents. The widespread tolerance of abuse and female inferiority needs to be addressed openly and dispassionately to change persistent gender stereotypes.

Exposure to ST products is associated with favorable gender attitudes among females, but the pattern is not as clear among males. ST only recently introduced features that explore gender issues explicitly. Efforts need to be directed toward eradication of these harmful beliefs.

\section{Self Efficacy and Self Confidence}

The majority of young people feel happy the way they are, although many lack confidence in their position in the household or in school. A third of the adolescents feel that their friends are better than they are, but most feel they are as skilled as others their age. About a third of the respondents doubt they have a bright future, particularly among those who are out of school or live in rural districts. More probing data collection is needed in order to determine whether these self-doubts reflect subjective feelings of inadequacy, or accurate perceptions of skills, intelligence, relative wealth, or other factors that shape young people's environments.

Adolescents, particularly girls, who are exposed to two or three ST items, are significantly more likely to report higher self confidence than those who are not exposed to any item. Thus ST is improving the selfassuredness of many young women in Uganda, an attribute that is likely to enable resilience in other aspects of their lives.

\section{Knowledge of STIs}

The ST products seem to have been particularly effective on the topic of STIs, as a higher proportion of those living in high media intensity districts, and those exposed to higher numbers of ST materials, are more likely than their counterparts to know about other STIs. Males, urban residents, and those in school (all associated with higher exposure to ST) are most likely to know that other diseases besides HIV/AIDS are transmitted through sexual intercourse. 


\section{Use of Health Facility Services}

About 20 percent of the respondents aged 15 to 19 years had visited a health facility for contraceptives, pregnancy tests, or voluntary counseling and testing for HIV; most used public facilities. Those in urban areas and those with high exposure to ST products were more likely than their counterparts to visit a facility, probably due to the accessibility of services in urban areas and the emphasis by ST on encouraging health-seeking behaviors.

\section{Communication with Parents}

Parents remain important in the sexual socialization of adolescents and ST has been involved in efforts to foster better parent-child communication. The data suggest that ST has been successful: controlling for demographic factors, exposure to ST materials was significantly associated with ever having talked with parents about ASRH matters for both male and female adolescents. Incremental exposure to ST materials was associated with an incremental likelihood of having talked with parents, and at the highest level of exposure, both male and female adolescents were four times as likely to have talked with their parents, compared to those who had not been exposed. Finding ways to bridge the communication gap between children and parents is crucial. Parents can have a chance to help their children set clear rules, talk about what is right and wrong, delay sexual debut, and provide a much-needed source of support during these complex and vulnerable years. Therefore the association between exposure to ST materials and parentchild communication is a welcome finding. The ST materials can be important vehicles through which to model good parent-child communication, to provide accurate and age-appropriate information to parents, and to encourage both sides to reach out to each other.

\section{Support if Child Sexual Abuse Attempted}

Most young people say they have someone to tell if they were pressured to have sex. Living in high media intensity districts and exposure to more ST materials is associated with higher proportions reporting someone to tell, indicating that messages about turning to a trusted adult, in most cases identified by the adolescents as a parent, are being heard and accepted. Girls seem to feel more confident that they can tell someone about abuse, and those exposed to ST products were more confident than those not exposed. Fewer young boys report having someone to tell about abuse; they are also the group least likely to express confidence in telling someone about it. This may suggest an area that should be addressed; while efforts have focused on girls, there may be a need to turn attention to the youngest boys.

\section{Sexual Activity Among Adolescents}

About a quarter of the respondents reported that they have a boyfriend or girlfriend; most were among the older youth. Those reporting more exposure to ST materials and those living in high media density districts were somewhat more likely to report having a boyfriend or girlfriend; the multivariate analysis found little association among males and a slight association for girls. The association may also be confounded by residence in urban areas, with its greater opportunities for boys and girls to meet, mix, and spend time together. 


\section{Hgrizons}

Fifteen percent of boys and 9 percent of girls had ever had sex. As has been demonstrated in other countries, school attendance appears to exert a protective effect, with three times more out-of-school youth reporting sexual activity compared with those in school. The bivariate analysis shows that greater exposure to the ST program is associated with a small increase in sexual activity, but this is not borne out statistically in the multivariate analysis; indeed, exposure to ST appears to be associated with a lower likelihood of ever having had sex among males, but the pattern among females is not statistically significant.

Nearly half the sexually active adolescents commenced their sexual careers out of love, followed by curiosity. However, nearly one in five sexually active females was "forced" into sex, indicating that sexual coercion is a real risk for HIV in the study population. It means that the efforts ST is making to empower females while instilling responsibility among males should be continued and strengthened. It also suggests that sexual debut among many adolescent females presents a very real threat for HIV.

Half of the sexually active boys and nearly two-thirds of sexually active girls had had only one partner. More youth living in high media density districts reported having only one lifetime partner, indicating that they may be responding to safer sex messages to be monogamous if they are sexually active. Males with greater exposure to ST products were more likely to report no partners in the prior 12 months, suggesting that they are influenced to resume secondary abstinence. This means that ST activities have contributed to significant proportions of youth who are now not being exposed to heterosexual transmission of HIV.

About 30 percent of the adolescents had received gifts for sex during the prior year (nearly equal proportions of boys and girls). However, boys were four times more likely to report having given a gift for sex. Twice as many out-of-school youth report giving or receiving a gift or money for sex. It seems that transactional sexual exchange is an important strategy among those out of school. Exposure to ST media appears to reduce the acceptability of transactional exchanges.

While 41 percent of sexually active youth had "no plans” with their most recent partner, more than a quarter planned to marry theirs, with higher proportions of older youth, those in secondary school, and those out of school saying this. Given that greater exposure to ST products is associated with higher percentages reporting planning to marry, particularly among males, it is possible that these youth are adopting norms of fidelity promoted through ST as well as other sources in Uganda's comprehensive HIV prevention campaign. Those with less exposure are twice as likely to say they are simply friends with their partner. Higher exposure to ST products is also associated with current partner being a student, perhaps in response to ST media advice to avoid "sugar daddies" and "sugar mommies." All these factors contribute to reducing HIV risk among Ugandan adolescents.

\section{Condom Use at Last Sex}

While ST has considered whether to limit discussion of condom-related topics in its materials, it appears that exposure to ST products is associated with some increase in condom use, but the relationship is not statistically significant, largely due to the small sample size limiting statistical analysis. Half of the girls and 41 percent of boys reported having used condoms at their last intercourse. While two-thirds of the boys reported being responsible for using condoms, more than half the girls reported taking the initiative to use them. 


\section{Reasons for Never Having Sex}

Fear of HIV is the most pronounced reason for never having had sex, but this needs to be considered in the context that many of these young people have not yet had an opportunity to be sexually active. Protective messages may have been absorbed and acted upon, but it is also likely that many of these young people have not yet found themselves in a situation to make the choice to advance or delay their sexual debut. The sizeable proportion saying they "are not ready," "don't want to," or "are not interested" underscores the reality that many young people monitor their sexual maturation responsibly.

While it appears that exposure to more ST products is associated with smaller proportions of youth saying they are not ready or do not want to have sex, this is partially due to the far larger share of the total saying that they fear contracting HIV. ST seems to have affected young people's awareness of the disease and their assessment of personal risk, allowing them to articulate this as a specific concern shaping their decision to remain abstinent.

\section{HIV Testing}

Seven percent of the full sample and 17 percent of the sexually active participants had been tested for HIV. Urban and older youth were more likely to have been tested (they are also those most likely to be sexually active, so this is not surprising). Exposure to ST materials was clearly associated with having been tested (especially among those exposed to all three ST products), and with knowing whether a partner had been tested. Indeed, multivariate analysis shows that respondents exposed to all three ST items were more than three times as likely to have been tested for HIV themselves.

\section{Conclusion}

This survey presents a rich source of information for programmers who are involved in ASRH. It indicates that many Ugandan adolescents have benefited from ST activities, and greater exposure is associated with greater benefits. Among both males and females, exposure to ST activities is associated with greater ASRH knowledge, more balanced attitudes toward condoms, and having communicated with parents about ASRH issues. The results also show that for girls, exposure to ST materials was further associated with greater self assuredness, greater sense of gender equity, and the likelihood of having a boyfriend but not having a sexual relationship. Among males, ST exposure was associated with lower likelihood of sexual activity, greater likelihood of resuming abstinence, and a greater likelihood of taking relationships with girls seriously. Thus ST may have protected many boys from HIV by helping them stop sexual activity or delay starting it all together. There is a need for programs to expand on the effort that ST has begun, to help young Ugandans remain HIV-free. 


\section{Hgrizons}

\section{References}

Grunseit, A. and S. Kippax. 1993. "Effects of sex education on young people's sexual behavior." Geneva: World Health Organization.

Kiragu, Karusa et al. 2007. “Straight Talk Campaign in Uganda: Parent survey.” Uganda: Straight Talk Foundation.

Ministry of Health (MOH) [Uganda] and ORC Macro. 2006. Uganda HIV/AIDS Sero-behavioural Survey 2004-2005. Calverton, Maryland, USA: Ministry of Health and ORC Macro.

Neema, Stella et al. 2006. “Adolescent sexual and reproductive health in Uganda: results from the 2004 Uganda national survey of adolescents,” Occasional Report no. 25. New York: Guttmacher Institute. 


\section{Appendix 1 Sample Design}

The community-based survey targeted about 2,100 adolescents aged 10 to 19 years in six districts, namely Apac, Arua, Ntungamo, Kamuli, Kisoro, and Soroti. These districts were selected to provide a diverse geographic distribution of ST activities, including sites where ST had not been implemented, to serve as an artificial control. The sample size was calculated to enable an estimation of several indicators with 95 percent confidence and 80 percent power. It also accommodates a 15 percent non-response rate, and a 35 percent cluster effects cushion ${ }^{8}$. The calculated sample size was 342 households per district, translating into a total of 2,052 households in the survey. Of these, 2,052 interviews were to be among adolescents and 512 among parents.

\section{Sample Frame}

In Uganda, there are about 70 administrative districts, and each district is divided into a county, subcounty, and parish. On average, each of the districts selected for the survey has four to seven counties, and each county can have anywhere from two to ten sub-counties. The population in each sub-county varies, but can be anywhere from 15,000 to 50,000 individuals. In each participating district, two counties were selected for data collection, and within each county, two sub-counties and two parishes each were selected. Thus a total of 12 counties, 24 sub-counties, and 48 parishes participated in the survey.

The UBOS has divided each parish into an enumeration area (EA). The UBOS also has a list of all households in Uganda, which is the basis on which national samples such as the UDHS sample are drawn. A recent household survey of adolescents conducted by ORC/Macro and Alan Guttmacher Institute (AGI) also used the UBOS household list. The STF survey drew from the same UBOS sample.

Two thousand fifty-two households were selected across the six districts, translating into 342 households per district and 171 households per county. Because the survey did not purport to provide district estimates, the interviews were distributed evenly across the districts, and no proportionate allocations were attempted. The sample was drawn in a way to accommodate refusals and not-at-homes. Thus an additional 20 percent of households per district were listed to provide a back-up where an interview was not possible.

\section{Selection of Respondents}

In each household, one eligible adolescent was identified. If there was more than one eligible adolescent, a table of random numbers was used to identify the one to be interviewed. Where the adolescent was a minor (i.e., under 18 years of age), parental consent was sought to interview him/her. Informed consent of the minor was also sought, even if parental/guardian consent was obtained. When an interview was declined by either the parent/guardian or by the adolescent, a household from the back-up sample was

\footnotetext{
${ }^{8}$ The variables used to calculate the sample size were: a) how to avoid HIV; b) discussion of abstinence; c) discussion of condoms; d) any exposure to ST activities and e) how to avoid HIV; (30 percent). The largest sample, 512 respondents per district, was taken as the operational sample.
} 


\section{Hgrizons}

identified. As is the standard practice with the UDHS, visiting adolescents were eligible if they spent the prior night at the household. Also, like the UDHS, households headed by children under the age of 18 were excluded in the sample, because parental consent cannot be obtained. The study excluded married adolescents.

Efforts were made to interview a male or female adolescent in alternate households, in order to produce as close to a 50/50 split as possible. In cases in which a back-up household was selected, the gender of the original respondent sought was maintained. The task assignments were such that same-sex interviews were conducted; i.e., male interviewers interviewed male respondents, and female interviewers interviewed female respondents.

In 25 percent of the households, interviews of both a parent and an adolescent were conducted. Efforts were made to interview an equal number of mothers and fathers. A total of 368 mothers and 368 fathers were included in the sample. 


\section{Appendix 2 \\ Variable Definitions for Multivariate Analysis}

\begin{tabular}{|c|c|}
\hline Variable & Definition \\
\hline ST exposure & $\begin{array}{l}0=\text { Not exposed to any ST items } \\
1=\text { Exposed to } 1 \text { item } \\
2=\text { Exposed to } 2 \text { items } \\
3=\text { Exposed to all } 3 \text { items assessed }\end{array}$ \\
\hline Age & $\begin{array}{l}\text { Q103: } \\
\text { Age in years (continuous variable) }\end{array}$ \\
\hline Radio & $\begin{array}{l}\text { Q301: } \\
\text { Listens 0-3 times versus } 4+\text { times a week }\end{array}$ \\
\hline Location & $\begin{array}{l}\text { Currently residing in an urban (1) or rural (2) area (generated from sampling and } \\
\text { household listing process) }\end{array}$ \\
\hline Living arrangements with parents & $\begin{array}{l}\text { Q1001: } \\
\text { Currently lives with both parents versus lives with one versus lives with none }\end{array}$ \\
\hline Schooling status & $\begin{array}{l}\text { Q110: } \\
\text { Currently enrolled versus currently not enrolled in a school }\end{array}$ \\
\hline Knowledge & $\begin{array}{l}\text { Q600 } \\
\text { 1. A girl cannot get pregnant the first time she has sex } \\
\text { 2. A girl cannot get pregnant if she has sex standing up } \\
\text { 3. A person who looks healthy can be infected with the AIDS virus } \\
\text { 4. It is possible to cure AIDS } \\
\text { 5. The AIDS virus can be passed from a pregnant mother, if she is infected, to her } \\
\text { unborn child } \\
\text { Correct answer scored } 1 \text { point, range of scores: } 0-5 \text { points } \\
\text { Dichotomized: } 0-3=\text { low knowledge, } 4-5=\text { high knowledge }\end{array}$ \\
\hline Attitudes toward gender & $\begin{array}{l}\text { Q900: } \\
\text { 1. When money is scarce and the family cannot send all children to school, boys should } \\
\text { 2. It is ok for boys to have sex before getting married } \\
\text { 3. It is ok for girls to have sex before marriage } \\
\text { 4. Girls are generally not as intelligent as boys } \\
\text { 5. A woman should tolerate abuse from her husband in order to keep her family together } \\
\text { 6. When it comes to sex, it is the man who should have the final word } \\
\text { 7. There are times when women deserve to be beaten by their husbands } \\
\text { 8. A girl who becomes pregnant while in school should be expelled } \\
\text { 9. Boys who have many girlfriends are "powerful" } \\
\text { 10. A boy who makes a girl pregnant while he is in school should be expelled } \\
\text { Desired response scored } 1 \text { point; range of points: } 0-10 \text { points } \\
\text { Dichotomized: } 0-4=\text { negative attitudes, } 5-10=\text { positive attitudes }\end{array}$ \\
\hline
\end{tabular}




\section{Hgrizons}

\begin{tabular}{|c|c|}
\hline Variable & Definition \\
\hline Attitudes toward condoms & $\begin{array}{l}\text { Q600: } \\
\text { 1. Condoms are an effective way of protecting against sexually transmitted infections if } \\
\text { 2. Ged properly } \\
\text { 3. Buying a condom is the responsibility of males only } \\
\text { 4. Using a condom is a sign that your partner does not trust you } \\
\text { Desired response scored } 1 \text { point; range of points: } 0-4 \text { points } \\
\text { Dichotomized: } 0-1=\text { negative attitudes, } 2-4=\text { positive attitudes }\end{array}$ \\
\hline Parent-child communication & $\begin{array}{l}\text { Q1004: Has any of your parents/guardians ever talked to you about issues related to } \\
\text { sexuality, growing up, relationships between boys and girls, etc.? } \\
\text { Yes-no response }\end{array}$ \\
\hline Self confidence & $\begin{array}{l}\text { Q1100 } \\
\text { 1. I am happy the way I am } \\
\text { 2. I don't feel I am as important to my family as other family members } \\
\text { 3. I feel that most of my friends are better than me } \\
\text { 4. I feel that I can do things as well as most people my age } \\
\text { 5. I do not feel like I have a bright future } \\
\text { 6. FOR GIRLS: I wish I was born as a boy instead of a girl; FOR BOYS: I wish I was } \\
\text { 7. I am a girl instead of a boy } \\
\text { Desired response scored } 1 \text { point, range of points }=0-7 \\
\text { Dichotomized: } 0-4=\text { low self esteem, } 5-7=\text { high self esteem }\end{array}$ \\
\hline Awareness of one's HIV status & $\begin{array}{l}\text { Q1500: We do not want to know your results but have you been tested for HIV? } \\
\text { Yes-no response }\end{array}$ \\
\hline Having a girl friend or a boyfriend & $\begin{array}{l}\text { Q1414: Have you ever had a girlfriend (for males)/boyfriend (for females)? } \\
\text { Yes-no response }\end{array}$ \\
\hline Sexually experienced & $\begin{array}{l}\text { Q1415: Have you ever had sex? } \\
\text { Yes-no response }\end{array}$ \\
\hline Now practicing secondary virginity & $\begin{array}{l}\text { Q1421: } \\
\text { Referring just to the past } 12 \text { months, how many times have you had sex? } \\
\text { Secondary virgins defined as those who responded "zero times" }\end{array}$ \\
\hline Used a condom at last sex & $\begin{array}{l}\text { Q1429: } \\
\text { The last time you had sex, was a condom used? } \\
\text { Yes-no response }\end{array}$ \\
\hline Seriousness of relationship & $\begin{array}{l}\text { Q1426: } \\
\text { Thinking again about your last partner, what are your plans with him/her? } \\
\text { Options were: 1-Plan to marry; 2-We are dating; 3-We are just friends; 4-We had just } \\
\text { met; 5-We already broke up; 6-No plans at all; 7-Don't know/not decided } \\
\text { Responses dichotomized as: Serious relationship = Plan to marry or dating; Casual } \\
\text { relationship = all the others. }\end{array}$ \\
\hline
\end{tabular}




\section{Hgrizons}

Horizons is a global operations research program designed to:

- Identify and test potential strategies to improve HIV/AIDS prevention, care, and support programs and service delivery.

- Disseminate best practices and utilize findings with a view toward scaling up successful interventions.

\section{(2) Population Council}

Horizons is implemented by the Population Council in collaboration with

- International Center for Research on Women (ICRW)

- International HIV/AIDS Alliance

- PATH

- Tulane University

- Family Health International (FHI)

- Johns Hopkins University

For more information, please contact:

Horizons Program, Communications Unit 4301 Connecticut Avenue, NW Suite 280 Washington, DC 20008 USA

Tel: 202-237-9400

Fax: 202-237-8410

Email: horizons@pcdc.org www.popcouncil.org/horizons 